\title{
Sex differences in the genome-wide DNA methylation pattern and impact on gene expression, microRNA levels and insulin secretion in human pancreatic islets
}

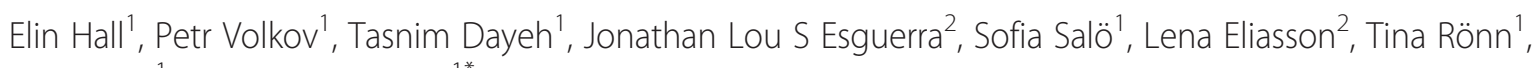
Karl Bacos ${ }^{1}$ and Charlotte Ling ${ }^{1 *}$

\begin{abstract}
Background: Epigenetic factors regulate tissue-specific expression and X-chromosome inactivation. Previous studies have identified epigenetic differences between sexes in some human tissues. However, it is unclear whether epigenetic modifications contribute to sex-specific differences in insulin secretion and metabolism. Here, we investigate the impact of sex on the genome-wide DNA methylation pattern in human pancreatic islets from 53 males and 34 females, and relate the methylome to changes in expression and insulin secretion.

Results: Glucose-stimulated insulin secretion is higher in female versus male islets. Genome-wide DNA methylation data in human islets clusters based on sex. While the chromosome-wide DNA methylation level on the X-chromosome is higher in female versus male islets, the autosomes do not display a global methylation difference between sexes. Methylation of 8,140 individual X-chromosome sites and 470 autosomal sites shows sex-specific differences in human islets. These include sites in/near AR, DUSP9, HNF4A, BCL11A and CDKN2B. 61 X-chromosome genes and 18 autosomal genes display sex-specific differences in both DNA methylation and expression. These include NKAP, SPESP1 and APLN, which exhibited lower expression in females. Functional analyses demonstrate that methylation of NKAP and SPESP1 promoters in vitro suppresses their transcriptional activity. Silencing of Nkap or Apln in clonal beta-cells results in increased insulin secretion. Differential methylation between sexes is associated with altered levels of microRNAs miR-660 and miR-532 and related target genes.
\end{abstract}

Conclusions: Chromosome-wide and gene-specific sex differences in DNA methylation associate with altered expression and insulin secretion in human islets. Our data demonstrate that epigenetics contribute to sex-specific metabolic phenotypes.

\section{Background}

Epigenetic factors such as DNA methylation are known to play important roles in tissue-specific gene expression, cell differentiation and parental imprinting. DNA methylation is also a key factor in X-chromosome inactivation, which takes place in all female mammalian cells to compensate for the extra X chromosome compared with male cells [1].

\footnotetext{
*Correspondence: charlotte.ling@med.lu.se

'Epigenetics and Diabetes Unit, Department of Clinical Sciences, Lund University Diabetes Centre, CRC, Lund University, Scania University Hospital, 20502 Malmö, Sweden

Full list of author information is available at the end of the article
}

In mammalian cells, DNA methylation mainly takes place on cytosines in CG dinucleotides [2].

Sex differences at the DNA methylation level have previously been studied in some human tissues and cell types, such as blood, heart muscle and liver [3-7]. One study, analyzing LINE-1 and Alu repeats to investigate DNA methylation in blood, found a small but significantly higher degree of methylation in males compared with females [5]. Another study in human cell lines discovered that the active female $\mathrm{X}$ chromosome displayed similar DNA methylation patterns to that of the male $\mathrm{X}$ chromosome [8]. Moreover, CpG islands within promoter regions revealed higher methylation levels in the 
inactive compared with the active female $\mathrm{X}$ chromosome. In contrast, the body of multiple genes displayed lower methylation levels in the inactive compared with the active female X chromosome [8]. Analysis of sex differences in DNA methylation on the autosomal chromosomes have either revealed no, few or small changes $[3,4,6,7]$. However, in cells found in saliva, females tend to have higher DNA methylation levels on both the X chromosome as well as the autosomes [9]. Many of these studies have only analyzed a limited number of genes and gene regions, such as the promoter region, and have not performed genome-wide analyses of DNA methylation. In addition, sex-specific differences in DNA methylation levels have, to our knowledge, not yet been studied in human pancreatic islets.

DNA methylation is known to control the transcriptional activity differently depending on the genomic location of the methylation [10-12]. It is generally accepted that DNA methylation of gene promoters can be a source of gene silencing. Moreover, DNA methylation of the first exon was recently shown to be associated with decreased gene expression [10]. In contrast, a positive correlation between DNA methylation and gene expression has been demonstrated when methylation takes place in gene bodies [11,13-15], possibly because of stimulation of transcriptional elongation [11]. There are also data suggesting that tissue-specific and/or differential DNA methylation mainly occurs at CpG shores, and not in CpG islands $[12,16]$.

Although previous studies have identified sex-specific differences in DNA methylation in, for example, saliva and blood $[3,6,9]$, most of these studies have not linked epigenetic differences to differential gene expression and altered metabolism. However, sex differences in metabolism are well established and females have been shown to be more insulin sensitive and secrete more insulin compared with males [17-19], as measured by disposition index [17] or insulinogenic index [19], respectively. Nevertheless, this is a complex area and additional studies exploring the impact of sex on metabolic phenotypes are needed [20].

Based on these data, we hypothesize that sex-specific differences in DNA methylation may be associated with differential gene expression and altered insulin secretion in human pancreatic islets. The aim of this study was therefore to study the impact of sex on the genome-wide DNA methylation pattern in human pancreatic islets and relate this to sex-specific differences in gene expression, microRNA levels and insulin secretion.

\section{Results}

Impact of sex on glucose-stimulated insulin secretion in human pancreatic islets

The clinical characteristics of the 53 male and 34 female donors of human pancreatic islets are shown in Table 1.
Table 1 Characteristics of all pancreatic islet donors divided by sex

\begin{tabular}{lccc}
\hline Phenotype & Males & Females & $P$-value \\
\hline $\mathrm{n}$ & 53 & 34 & \\
Age (years) & $56 \pm 11$ & $58 \pm 10$ & 0.7 \\
$\mathrm{BMI}\left(\mathrm{kg} / \mathrm{m}^{2}\right)$ & $25.6 \pm 3.0$ & $26.1 \pm 4.1$ & 0.7 \\
Hba1c $\mathrm{C}^{\mathrm{a}}(\%)$ & $5.6 \pm 0.5$ & $5.6 \pm 0.4$ & 0.6 \\
Stimulation index $\left(\mathrm{SI}^{\mathrm{b}}\right)$ & $6.2 \pm 5.8$ & $7.6 \pm 5.3$ & 0.03 \\
\hline
\end{tabular}

Data is expressed as mean \pm standard deviation. $P$-values are based on Mann-Whitney test. ${ }^{a}$ Data available for 45 males and 28 females. ${ }^{\text {b Data }}$ available for 48 males and 33 females. BMI, body mass index; HbA1c, hemoglobin A1c.

There were no significant differences in age, body mass index (BMI) or hemoglobin A1c (HbA1c) between the two sex groups. However, in vitro glucose-stimulated insulin secretion, measured as stimulation index (SI) [21], was higher in islets from females compared with males (Table 1). Additionally, we found no significant difference in islet purity $(P=0.27$; data not shown $)$ or $\beta$-cell content $(P=0.29$; Additional file 1) between female and male islets.

\section{Sex differences in the genome-wide DNA methylation pattern in human pancreatic islets}

We next evaluated if there are epigenetic differences between sexes in human pancreatic islets. The genome-wide DNA methylation pattern was analyzed with the Infinium HumanMethylation450 BeadChip array. After quality control, DNA methylation data were obtained for a total of 482,954 sites, excluding data on the Y chromosome. We next performed an unsupervised clustering of the islet DNA methylation data for all 87 donors. Figure 1A clearly shows that the genome-wide DNA methylation data in human islets cluster based on sex. However, after removing the $\mathrm{X}$ chromosome methylation data (11,150 sites) from the data set we could no longer detect any clustering based on sex (Figure 1B).

We then tested if the average degree of DNA methylation of all analyzed sites differed between males and females. There were no differences in the average degree of methylation between the sexes when analyzing the DNA methylation sites on all chromosomes (females $48.5 \pm 1.2 \%$ versus males $48.3 \pm 1.1 \%, P=0.48$ ) or when analyzing the DNA methylation sites on the autosomal chromosomes separately (females $48.5 \pm 1.2 \%$ versus males $48.5 \pm 1.1 \%, P=1.0$ ) (Figure $2 \mathrm{~A}$ ). However, when analyzing the average degree of DNA methylation of all analyzed sites on the X chromosome, females exhibited a higher degree of methylation compared with males (females $48.9 \pm 1.5 \%$ versus males $41.0 \pm 1.1 \%, P=4.7 \times 10^{-15}$ ) (Figure $2 \mathrm{~A}$ ).

To further dissect the impact of sex on DNA methylation in human pancreatic islets, we calculated the average DNA methylation levels of the analyzed sites based on either their functional genomic annotation (TSS1500 (the 


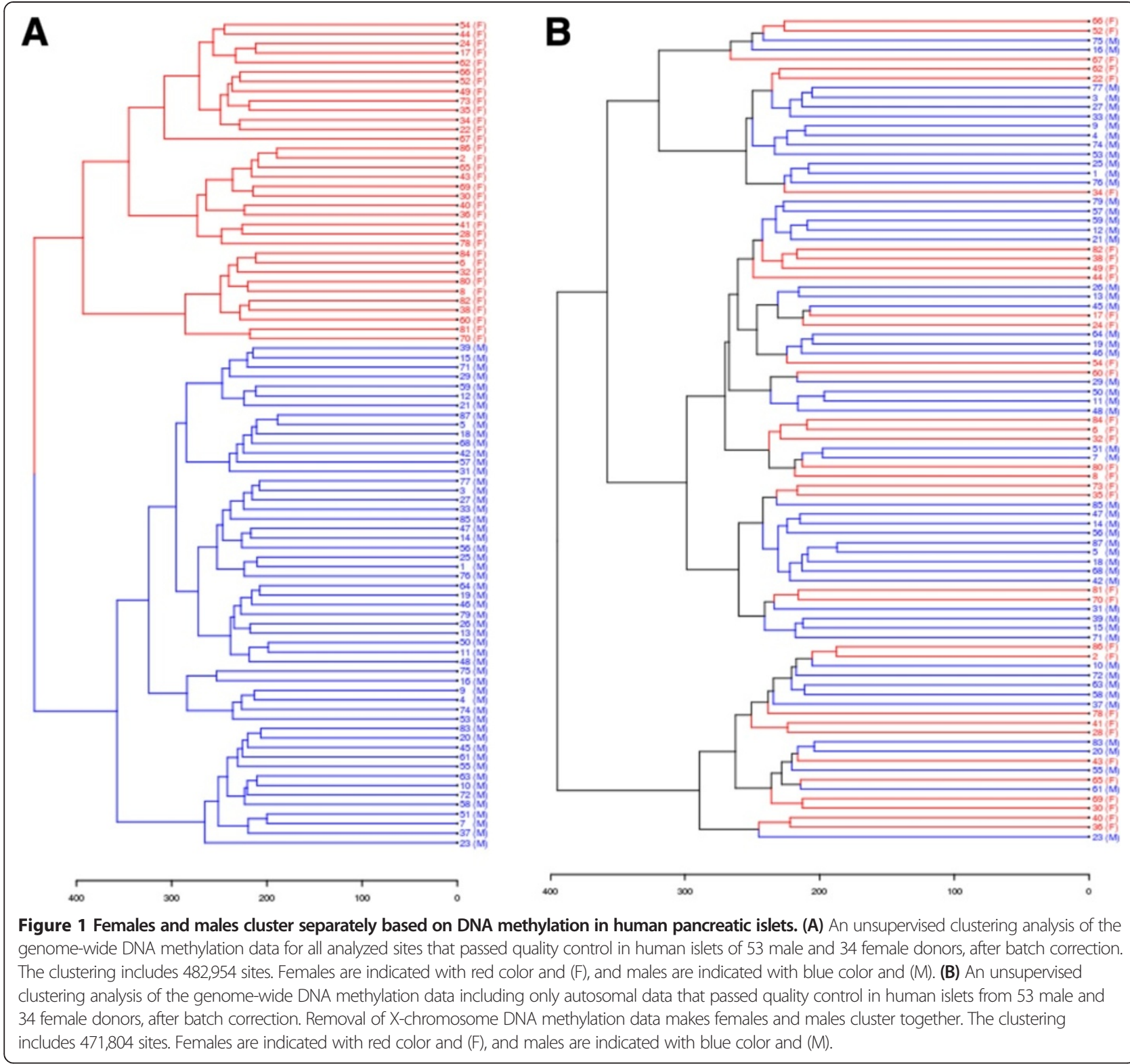

region 200 to 1,500 nucleotides upstream of the transcription start site (TSS)), TSS200 (the 200 nucleotides immediately upstream of the TSS), $5^{\prime}$ untranslated region (UTR), first exon, body, 3' UTR or intergenic) or the CpG content and neighborhood context [22]. This was done for the autosomal chromosomes and X chromosome separately. The average DNA methylation level of the studied genome regions did not differ significantly between males and females for the autosomal chromosomes (Figure 2B,C). For the $\mathrm{X}$ chromosome, however, all studied genome regions differed significantly between the sexes with false discovery rate (FDR) less than $5 \%(q<0.05)$ (Figure 2D,E). While the TSS1500, TSS200, 5' UTR, first exon, body and intergenic regions had higher average methylation levels in females compared with males, the 3' UTR region had a higher methylation level in males compared with females (Figure 2D). In addition, we found that females had higher average methylation levels compared with males for the shore regions as well as the CpG islands, while males had higher average methylation levels than females in the open sea and shelve regions (Figure 2E).

\section{Impact of sex on DNA methylation of individual sites in human pancreatic islets}

Since it is known that individual CpG sites exhibit differences in DNA methylation between the sexes on both the autosomal chromosomes as well as the $\mathrm{X}$ chromosome in, for example, blood cells [3,5-7], we further tested if the degree of DNA methylation of the 482,954 analyzed sites in human pancreatic islets differed in 


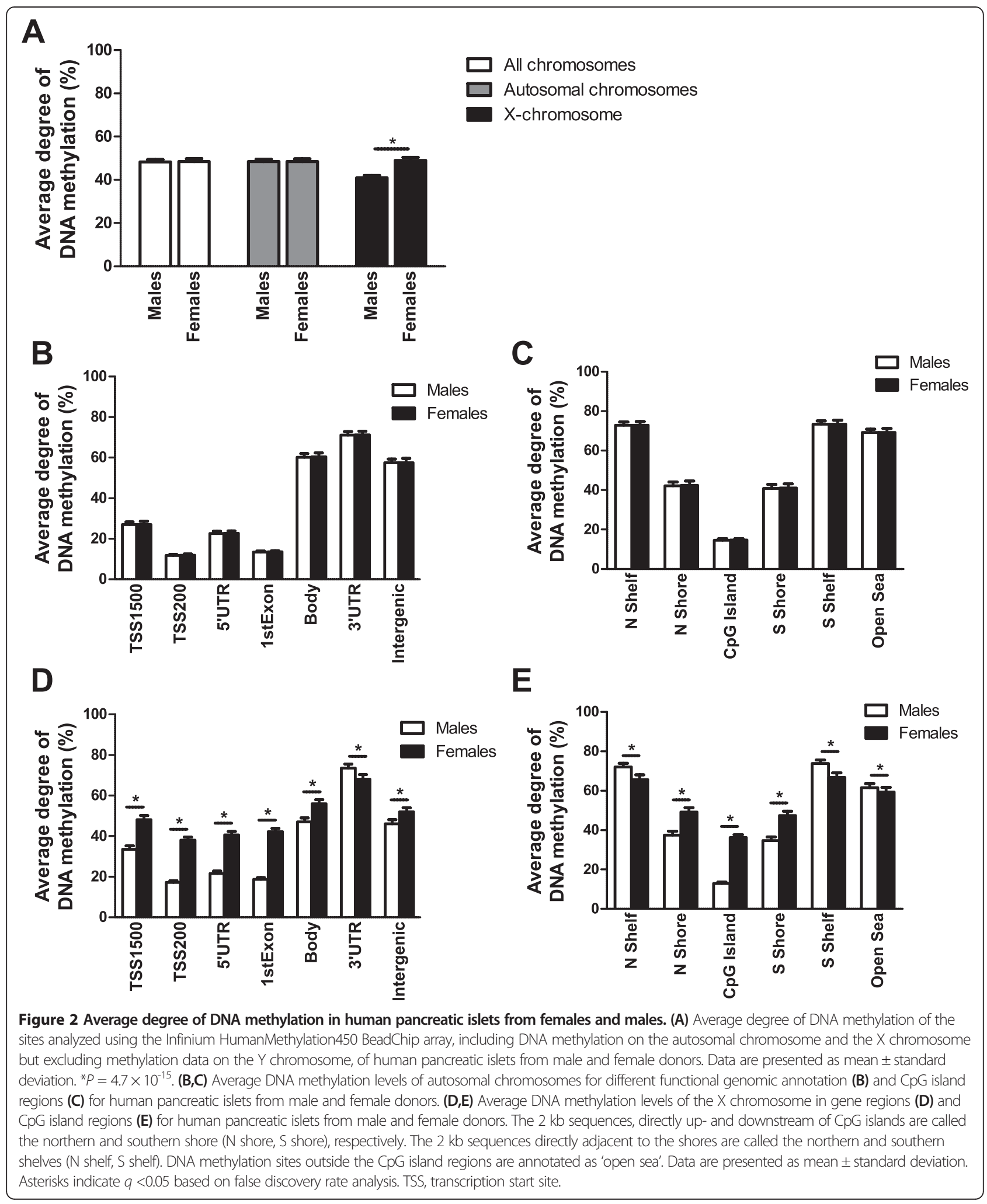

males compared with females. The DNA methylation data on the autosomal chromosomes and the X chromosome were analyzed separately using a linear regression analysis including batch, age, BMI, purity of the islets, days in culture and HbA1c as covariates. We identified 1,523 individual sites on the autosomal chromosomes 
that exhibited significant differences in DNA methylation due to sex with FDR less than 5\% $(q<0.05)$. Figure 3A,B shows the number of significant sites $(q<0.05)$ on the autosomal chromosomes distributed into 5\% intervals of absolute difference in DNA methylation levels between males and females. To increase the biological relevance of our DNA methylation data, we further filtered the data to include only significant sites with absolute differences in DNA methylation bigger than $5 \%$ (delta $\beta$-value $>5 \%$ ) due to sex. We found 470 autosomal sites that had an absolute difference in DNA methylation bigger than $5 \%$ between the two sexes. These sites had a fold change (males/females) spanning between 0.22 and 3.86. Of these 470 sites, 322 had higher methylation in females and 148 sites had higher methylation in males. These 148 and 322 significant sites correspond to 82 and 140 individual genes, respectively (Additional files 2 and 3).

Furthermore, out of the total 11,150 sites analyzed on the X chromosome, 10,224 (92\%) had a significant difference in DNA methylation based on sex with FDR less than $5 \%(q<0.05)$. These include 84 probes in non-CpG sites (that is, the $\mathrm{C}$ nucleotide is followed by an $\mathrm{A}$ or $\mathrm{T}$ ). Figure 3C,D shows the distribution of the absolute difference in DNA methylation levels of the significant sites on the $\mathrm{X}$ chromosome between males and females. Out of these 10,224 sites, 8,140 had an absolute difference in DNA methylation of more than $5 \%$. These 8,140 sites had a fold change (males/females) spanning between 0.041 and $6.43 ; 5,287$ sites had a higher methylation in females compared with males and 2,853 had a higher methylation in males compared with females (Additional files 4 and 5). Out of these 8,140 sites, 31 were non-CpG sites, with 5 non-CpG sites being higher methylated in females compared with males and 26 non-CpG sites being higher methylated in males compared with females. The 5,287 sites on the $\mathrm{X}$ chromosome with $>5 \%$ higher methylation in females correspond to 565 individual genes. The 2,853 sites on the X chromosome with $>5 \%$ higher methylation in males compared with females correspond to 757 individual genes out of a total of 890 genes on the $\mathrm{X}$ chromosome covered by the Infinium HumanMethylation450 BeadChip. Of note, 450 of these $\mathrm{X}$-chromosome genes have $\mathrm{CpG}$ sites with higher methylation in both females and males.

The distribution of autosomal and X-chromosome sites with a significant difference in DNA methylation $>5 \%$ between males and females is shown in Figure 3E-H. The distribution is based on the site location in relation to the functional genomic annotation (Figure 3E,G) or in relation to $\mathrm{CpG}$ islands (Figure 3F,H). We found that $\mathrm{CpG}$ sites with a different level of DNA methylation on autosomal chromosomes were underrepresented within the $5^{\prime}$ UTR and enriched in intergenic regions (Figure 3E). Furthermore, the significant autosomal DNA methylation data also showed enrichment in the CpG island region, while they were underrepresented in the southern shelf and in the open sea region (Figure 3F). For the $\mathrm{X}$ chromosome, we found that the significant DNA methylation sites were enriched within TSS200, 5' UTR and the first exon, while they were underrepresented in the gene body, 3' UTR and in intergenic regions (Figure 3G). Also, the significant Xchromosome methylation data showed enrichment in the $\mathrm{CpG}$ island region and underrepresentation in the shelves and open sea region (Figure $3 \mathrm{H}$ ).

Based on data by Chen et al. [23], we next tested if any of the Infinium probes that detected significant differences in DNA methylation between sexes in our cohort cross-react with alternative genomic locations. Three of the 113 possibly cross-reactive probes targeting the autosomal chromosomes (Additional file 6) have a perfect match to other locations in the genome, and 21 of the 346 possibly cross-reactive probes targeting the $\mathrm{X}$ chromosome have a perfect match to other locations in the genome (Additional file 7).

We also tested if any of the covariates included in the regression analysis had an impact on any of the individual sites that show significant differences in methylation $>5 \%$ between sexes. Here, we found that only purity of the islets was significantly associated with DNA methylation of 78 autosomal sites and 642 sites on the $\mathrm{X}$ chromosome (Additional files 8 and 9).

\section{Biological features of the genes that exhibit differential methylation in human islets based on sex}

We next performed a KEGG (Kyoto Encyclopedia of Genes and Genomes) pathway analysis using WebGestalt $[24,25]$ to identify biological pathways with enrichment of genes that exhibit differential DNA methylation in human islets based on sex. The pathway analysis was conducted with genes differing significantly in DNA methylation by at least $5 \%$ due to sex on either the autosomal chromosomes $(\mathrm{n}=220)$ or the $\mathrm{X}$ chromosome ( $\mathrm{n}=872$ ). The analysis of the autosomal chromosome genes was split into two separate analyses including either autosomal genes with a higher methylation in females or those higher in males. Two autosomal genes, FLNB and TFDP1, had a higher degree of DNA methylation, although at different $\mathrm{CpG}$ sites, in both females and males and these genes were subsequently included in the KEGG pathway analyses of genes with higher methylation in both sexes. Among the genes with higher methylation in females $(n=140)$ there was an enrichment of the cell adhesion molecule (CAM) pathway and among the genes with higher methylation in males $(n=82)$ there was an enrichment of the adipocytokine signaling pathway (Additional file 10). Pathway analysis on the X chromosome data did not generate any significantly enriched pathways. 


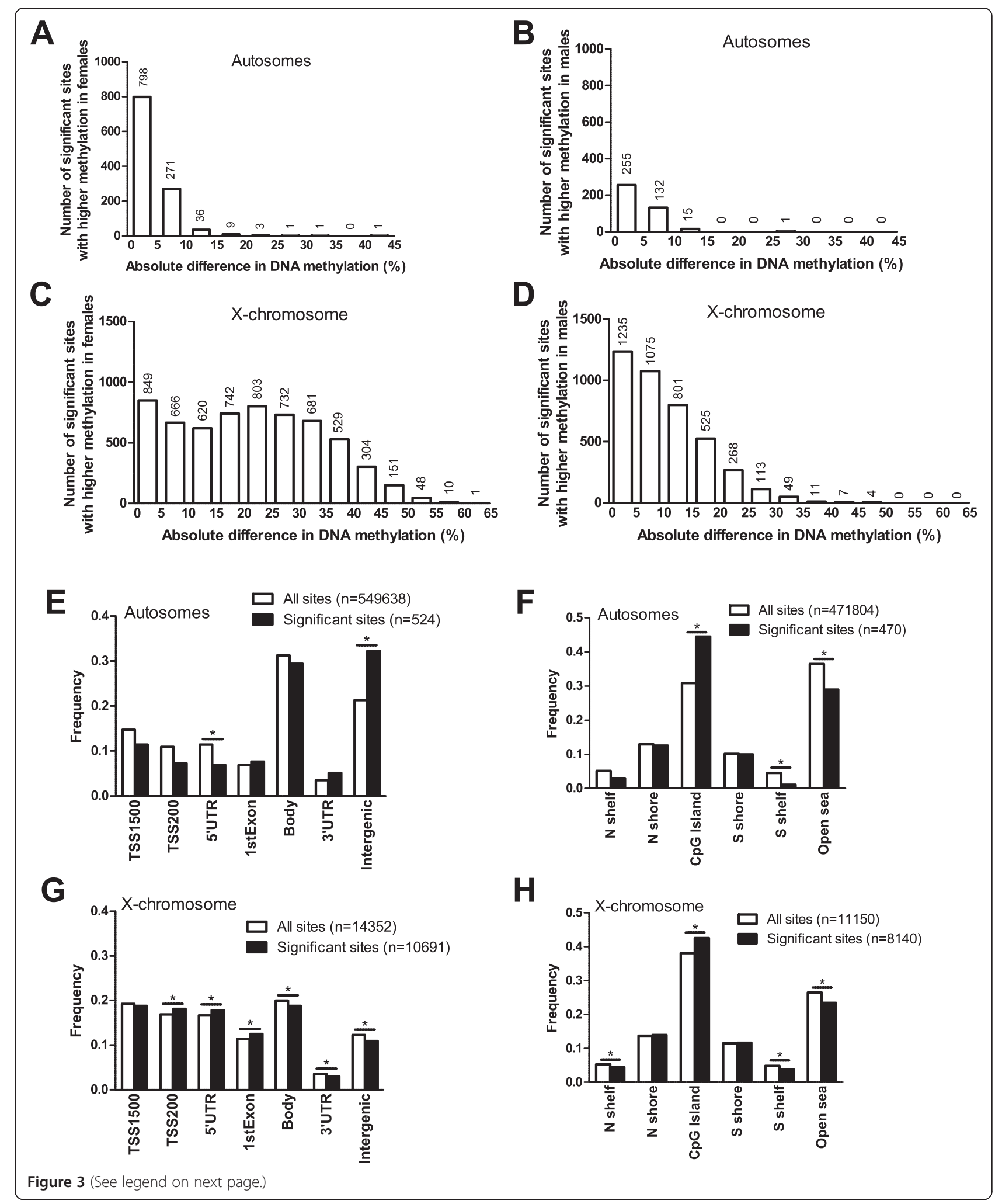




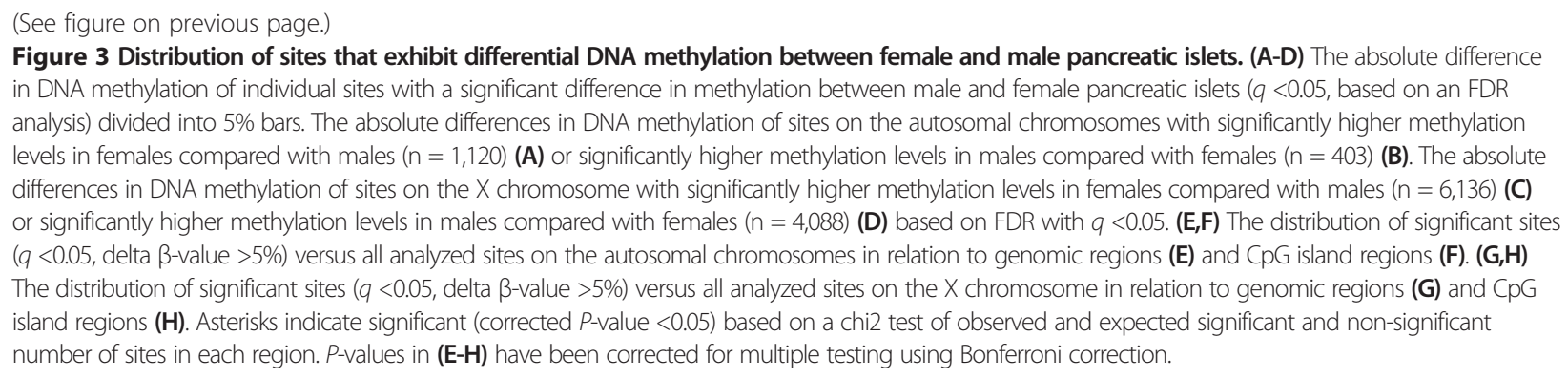

Genome-wide association study (GWAS) data point to islet defects as key mechanisms in the development of type 2 diabetes and suggest that there are sex differences in the genetic predisposition to diabetes and related metabolic traits [26,27]. We therefore tested if there are sex differences in the degree of DNA methylation of candidate genes for type 2 diabetes and related traits in human pancreatic islets, which may contribute to altered metabolism and affect the risk for disease. We used gene lists of candidate genes for type 2 diabetes, and candidate genes for type 2 diabetes-related traits based on the online catalog of published GWAS [28]. Included genes had a $P$-value threshold for GWAS SNP finding at $P<10^{-5}$. In total, the type 2 diabetes candidate gene list included 100 genes and 79 candidate genes for related traits. Sites annotated to 10 candidate genes for type 2 diabetes, including DUSP9, BCL11A, HNF4A, and $C D K N 2 B$, and 7 candidate genes for related metabolic traits (for example, ATP11A, ADCY5 and IRS1) had differential DNA methylation in human pancreatic islets based on sex (Additional files 11 and 12). Interestingly, DUSP9 is located on the $\mathrm{X}$ chromosome and had 16 CpG sites with an absolute difference in DNA methylation of more than $5 \%$ between males and females (Figure 4A).

Although most genes on one $\mathrm{X}$ chromosome are silenced in females, some genes are known to escape Xinactivation. We therefore checked if X-chromosome genes that show differential DNA methylation in male versus female pancreatic islets (Additional files 4 and 5) are previously known to escape X-chromosome inactivation based on experimental data in fibroblast-based systems from Carrel and Willard [29]. This analysis showed that out of the $565 \mathrm{X}$-chromosome genes containing sites with $>5 \%$ higher methylation in islets from female compared with male donors, 209 were previously shown to be completely silent on the inactivated $\mathrm{X}$ chromosome, while 125 partially and 34 entirely escaped inactivation (Additional file 13). The remaining genes were not analyzed in the previous study [29]. For the $757 \mathrm{X}$ chromosome genes with sites that are more methylated in islets from male compared with female donors, 191 were previously shown to be completely inactivated, while 134 partially and 21 entirely escaped inactivation (Additional file 14).

\section{Sex differences in DNA methylation are associated with differential gene expression in human pancreatic islets} Since DNA methylation may regulate gene transcription $[30,31]$, we further examined if any of the genes that exhibit differential DNA methylation due to sex also show different levels of expression in islets from male, compared with female, donors. Using microarray data, we identified 18 genes on the autosomal chromosomes (Additional files 15 and 16) and 61 genes on the $\mathrm{X}$ chromosome (Additional files 17 and 18) where differences in DNA methylation $(q \leq 0.05$, absolute difference in DNA methylation $>5 \%$ ) were also associated with differential gene expression in human islets $(P \leq 0.05)$. These include genes previously known to promote NF$\mathrm{\kappa B}$ activation (that is, NKAP; Figure 4B) [32], to affect pancreatic islet function (for example, $A P L N$; Figure 4C) [33], and to play a role during fertilization (that is, SPESP1; Figure 4D) [34]. Finally, based on literature search, genes with known function in the insulin secretion process and/or pancreatic islets function [33,35-39] (Figure 5) or with sex differences in normal or diseased tissues [40-51] (Figure 6) were found to be both differentially methylated and expressed between males and females.

\section{Sex differences in DNA methylation are associated with altered expression of microRNAs and their related target genes in human pancreatic islets}

DNA methylation of CpG sites annotated to microRNAs has been suggested to affect islet function in subjects with type 2 diabetes [52]. We therefore examined if CpG sites annotated to microRNAs exhibit differential DNA methylation in human pancreatic islets, based on sex. For autosomal chromosomes we found three microRNAs with significant differences in DNA methylation based on sex, namely $h s a-m i R-548 H 4$, hsa-miR-220B and $h s a-m i R-663 B$ (Additional files 2 and 3). Additionally, for the X chromosome, we found in total 160 sites annotated to microRNAs with differential DNA methylation between sexes, out of which 22 sites had higher methylation in females and 138 


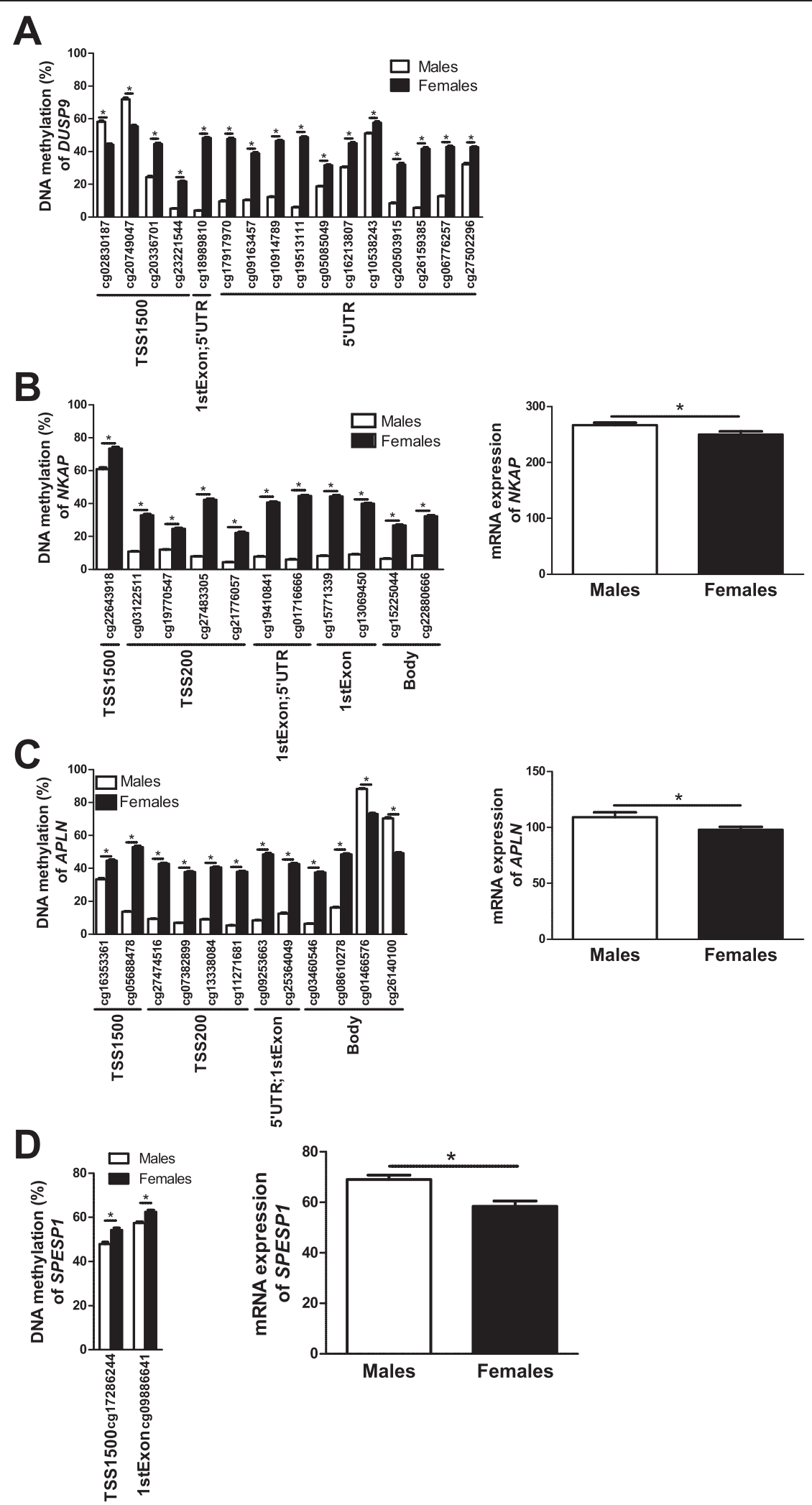

Figure 4 (See legend on next page.) 
(See figure on previous page.)

Figure 4 Impact of sex on DNA methylation and/or expression in human pancreatic islets of selected candidate genes. (A) DUSP9, a candidate gene for type 2 diabetes, is located on the $X$ chromosome and has numerous differentially methylated $\mathrm{CpG}$ sites between female and male human pancreatic islets. (B-D) Impact of sex on the DNA methylation level of CpG sites and gene expression of NKAP (B), APLN (C) and SPESP1 (D). Data are presented as mean \pm standard error of the mean. Asterisks indicate $q<0.05$ for DNA methylation and $P<0.05$ for expression

sites had higher methylation in males (Additional files 4 and 5). These sites correspond to six unique microRNAs with higher methylation in females and 59 unique microRNAs with higher methylation in males. Since DNA methylation may alter the expression of microRNAs and subsequently also the expression of their target genes [52], we further tested if any of the microRNAs that display differential DNA methylation due to sex also display altered expression in human islets. We found two microRNAs located on the X chromosome, $h s a-m i R-660$ and $h s a-m i R-$ 532, that exhibited lower DNA methylation and higher expression levels in pancreatic islets from female compared with male donors (Figure 7). We next used TargetScan
Human Release 6.2 (June 2012) [53] to find potential target genes of hsa-miR-660 and hsa-miR-532 (Additional files 19 and 20). Interestingly, six of the identified target genes showed lower expression in islets from female compared with male donors (Figure 7; Additional file 21).

\section{Technical validation of DNA methylation data in human pancreatic islets}

To technically validate the DNA methylation data from the Infinium HumanMethylation450 BeadChip, CpG sites annotated to NKAP (Figure 8A), APLN (Figure 8B) and GREB1 (Figure $8 C$ ) were analyzed with PyroSequencing. These sites were chosen as they had relatively large differences in DNA

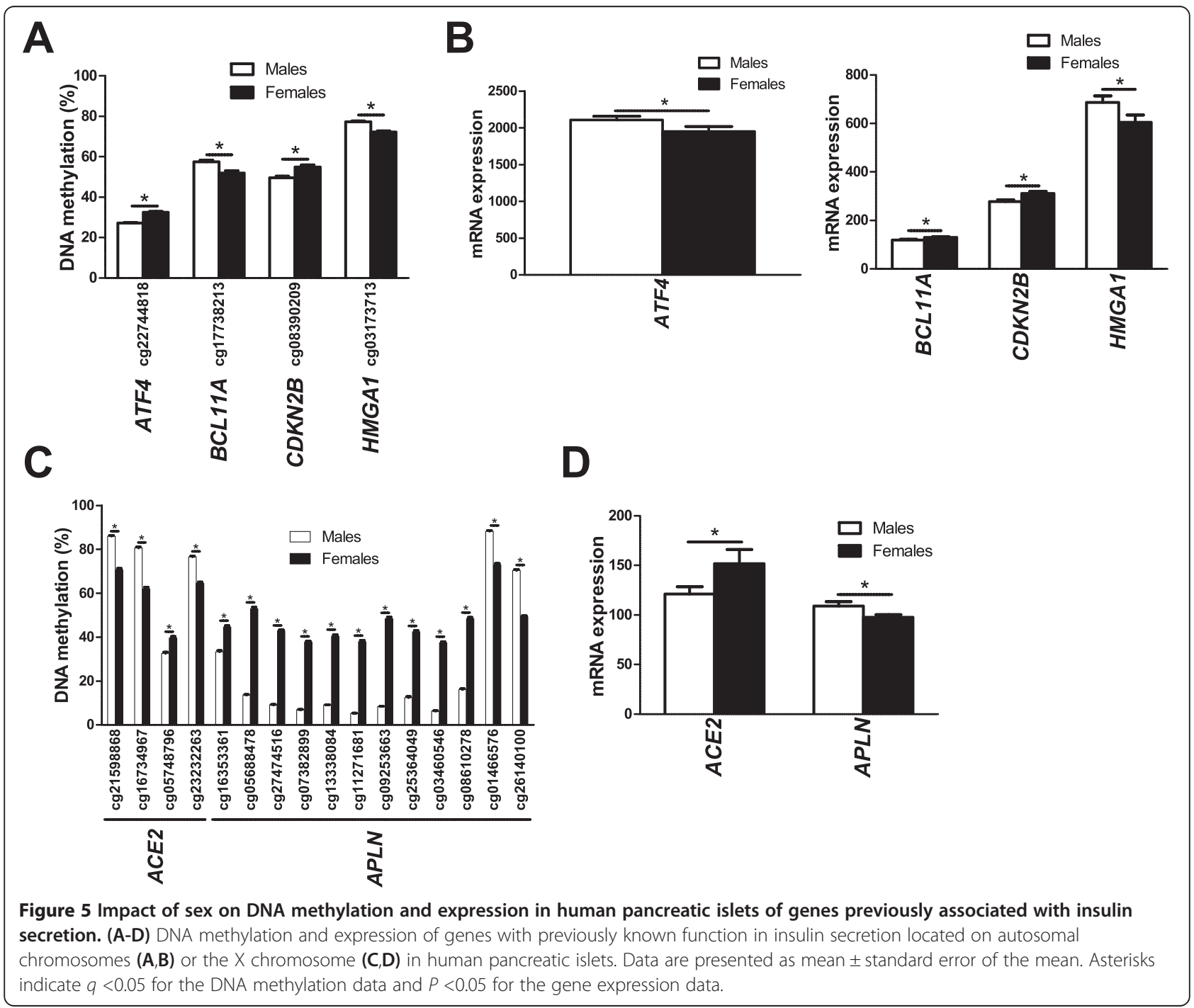




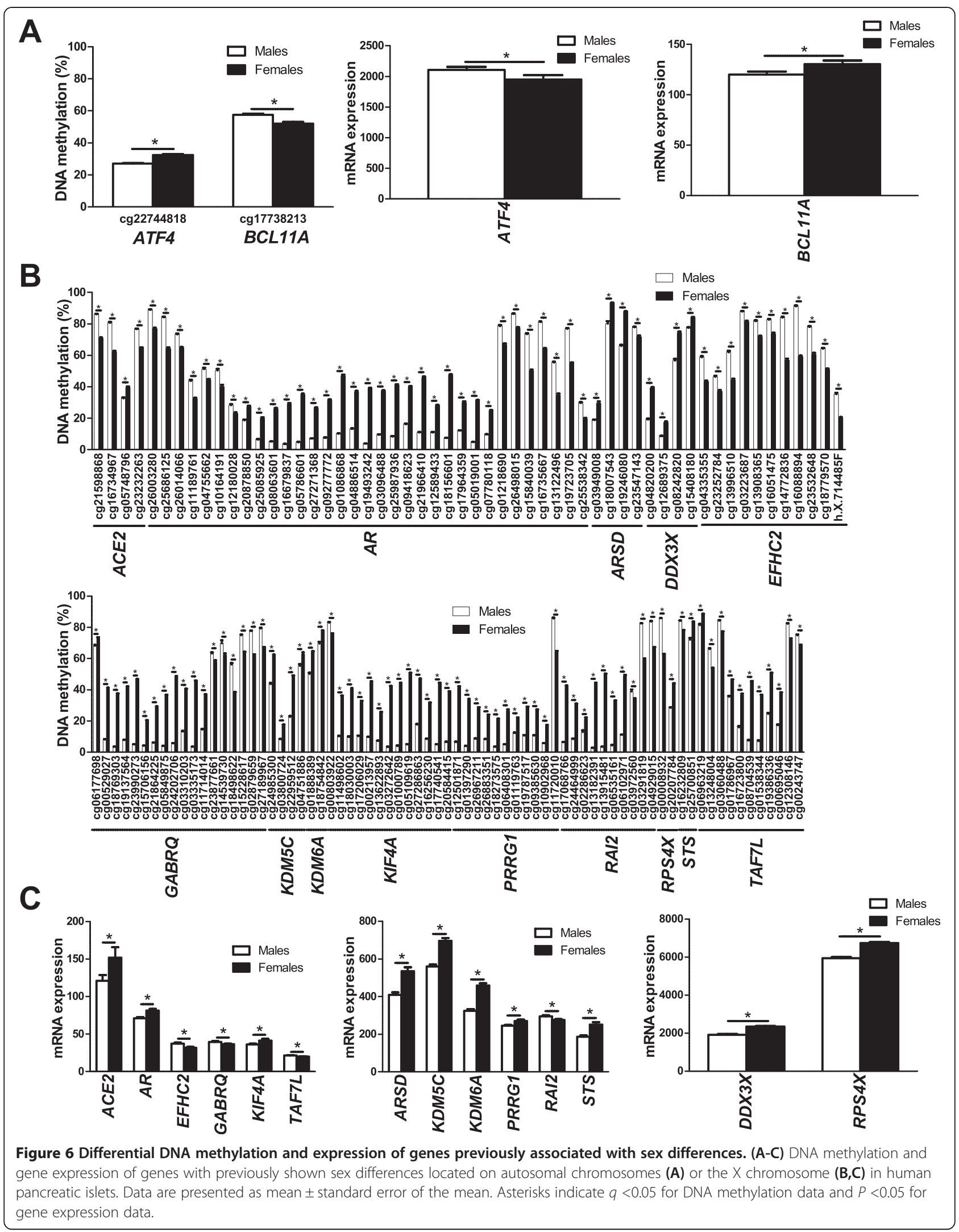




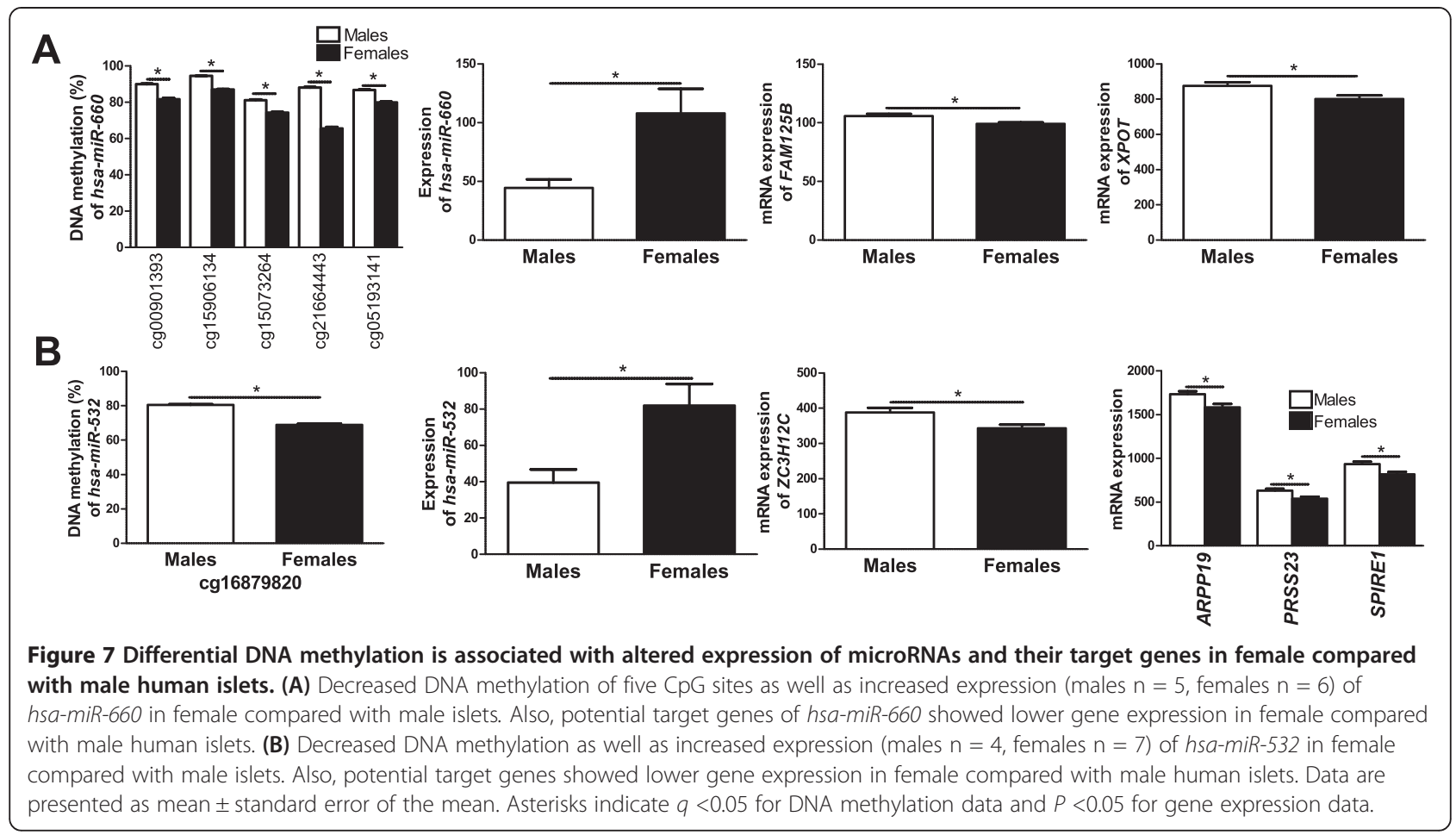

methylation between males and females. DNA from pancreatic islets from 32 males and 18 females was used for the technical validation. In agreement with the Infinium HumanMethylation450 BeadChip data, all three CpG sites showed differential DNA methylation in pancreatic islets from male compared with female donors and the differences in DNA methylation seen with PyroSequencing were similar to the differences seen with the Infinium HumanMethylation450 BeadChip (Figure 8). Interestingly, we also found significant differences in DNA methylation between sexes for all but one adjacent CpG site only covered by the PyroSequencing assays, that is, sites not included on the Infinium HumanMethylation450 BeadChip (Figure 8A-C).

Increased DNA methylation of the proximal promoters of NKAP and SPESP1 decreases reporter gene expression

DNA methylation in the proximal promoter region is generally associated with decreased transcriptional activity $[30,31]$. We therefore functionally tested if promoter methylation affects expression of two selected genes that exhibited both differential DNA methylation and expression in islets due to sex (Figure 4B,D). While NKAP is located on the $\mathrm{X}$ chromosome, SPESP1 is an autosomal gene located on chromosome 15 . The promoter region of NKAP contains several differentially methylated CpG sites $(q<0.05)$ and the mRNA expression of NKAP was lower in females compared with males $(P<0.05)$ (Figure 4B). SPESP1 has a higher degree of DNA methylation in the promoter and the first exon, in parallel with lower expression in female compared with male islets (Figure 4D). To functionally test if DNA methylation of the NKAP and SPESP1 promoters could influence their gene expression, we used a luciferase reporter assay. A 1,500 bp DNA sequence upstream of their respective TSSs was inserted into a $\mathrm{CpG}$ free vector containing the firefly luciferase gene. The constructs were then either mock-methylated or methylated using two different enzymes, HhaI and SssI, where HhaI methylates the internal CpG site in the GCGC sequence, and SssI methylates all CpG sites in the sequence. The numbers of $\mathrm{CpG}$ sites methylated by these enzymes in the 1,500 bp NKAP and SPESP1 promoter sequences are shown in Figure 9. SssI methylation of the NKAP promoter almost completely repressed the transcriptional activity of the reporter gene, while HhaI methylation did not significantly affect the transcriptional activity $(P=0.065)$, probably due to the low number of GCGC sequences in the promoter sequence of NKAP (Figure 9A). For the SPESP1 promoter, methylation with either enzyme caused a significant reduction in transcriptional activity, with methylation by HhaI having a stronger repressive effect on transcription than SssI (Figure 9B). It may seem surprising that methylation of fewer $\mathrm{CpG}$ sites by HhaI decreased the transcriptional activity of the SPESP1 promoter more than methylation by SssI. To further resolve why methylation by Hhal had a stronger repressive effect than SssI, we analyzed which transcription factors and repressive factors may bind to the SPESP1 promoter and tested if their binding motif may overlap with $\mathrm{CpG}$ sites methylated by HhaI or SssI. Using TFSearch [54] we found numerous putative binding sites 

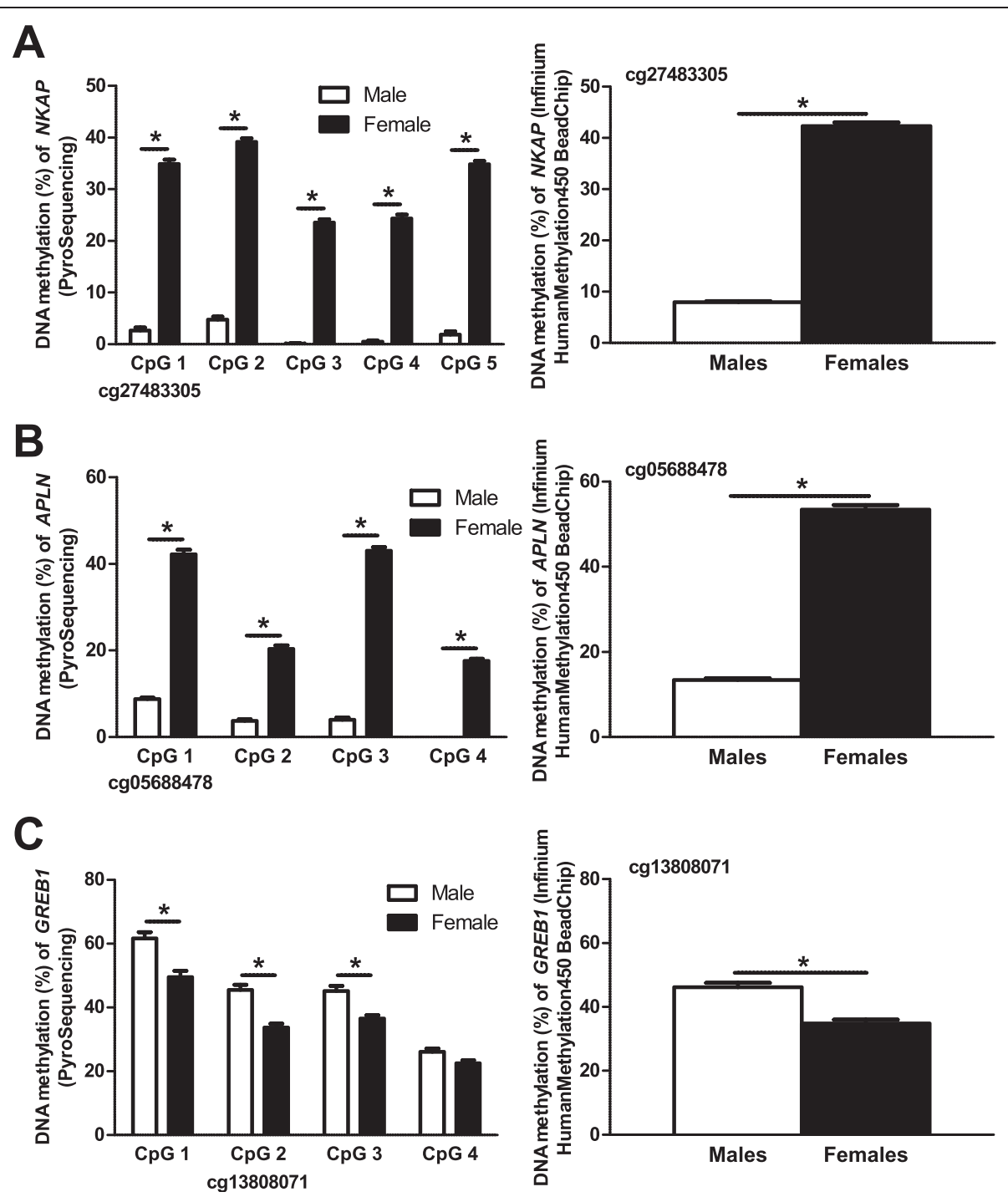

Figure 8 Technical validation of Infinium HumanMethylation450 BeadChip data using PyroSequencing. (A-C) The selected CpG site connected to NKAP (probe ID: cg27483305) (A), APLN (probe ID: cg05688478) (B) and GREB1 (probe ID: cg13808071) (C) showed similar differences in DNA methylation between males and females for both PyroSequencing and Infinium HumanMethylation450 BeadChip data. Numerous surrounding CPG sites in NKAP (A), APLN (B) and GREB1 (C) analyzed by PyroSequencing also show differential DNA methylation between male and female islet donors. Data are presented as mean \pm standard error of the mean. Asterisks indicate $P<0.0005$ for PyroSequencing data and $q<0.05$ for Infinium HumanMethylation450 BeadChip data. PyroSequencing data were calculated using a Mann-Whitney test.

for transcription factors with previously known repressive function in the SPESP1 promoter (Additional file 22). While the binding sites for many of these repressive factors overlap with or are in the immediate vicinity of $\mathrm{CpG}$ sites methylated by SssI, only three of these binding sites overlap with the GCGC sequence methylated by HhaI (Additional file 22). This may be an explanation for why methylation by HhaI had a stronger repressive effect on the transcriptional activity of SPESP1 than SssI - that is, methylation of $\mathrm{CpG}$ sites where repressive factors bind may result in higher gene transcription.
Silencing of Nkap, Apln and Bcl11a in clonal $\beta$-cells affects insulin secretion

The identified sex differences in islet DNA methylation and gene expression may contribute to the higher glucose-stimulated insulin secretion seen in pancreatic islets from females compared with males (Table 1; Additional files 15, 16, 17 and 18). To model the situation in human islets and elucidate whether altered expression of identified genes may affect insulin secretion, we used small interfering RNA (siRNA) to silence $N K A P$ and $A P L N$, two X-chromosome genes that showed increased 


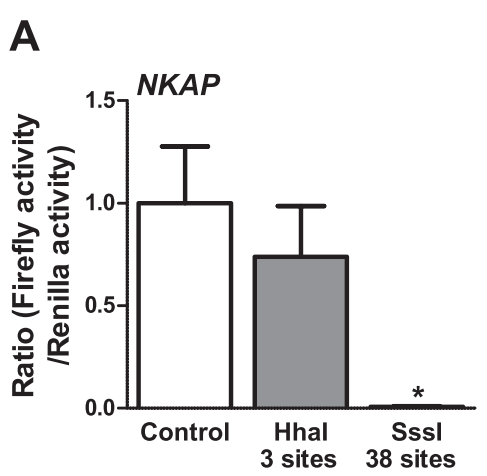

B

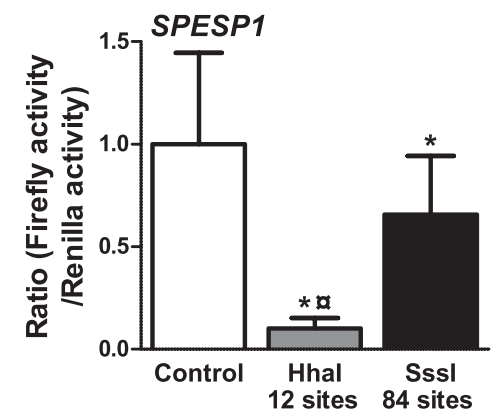

Figure 9 In vitro methylation of the NKAP and SPESP1 promoters decreased reporter gene activity. (A,B) The 1,500 bp promoter regions of NKAP (A) and SPESP1 (B) were inserted into the PCpGL basic vector. Promoter constructs were then methylated (gray and black bars) with Hhal or SsSl or mock-methylated (white bar) before transfection into clonal $\beta$-cells for $48 \mathrm{~h}$. After the $48 \mathrm{~h}$ transfection, the luciferase assay was run. The data were normalized with co-transfected renilla luciferase control vector and are the mean of five (NKAP) or nine (SPESP1) separate experiments of five replicates in each. Cells transfected with an empty PCpGL vector were used as background control for firefly luciferase results, and untransfected cells were used as a background for renilla luciferase results. Data were log-transformed and statistical tests calculated using ANOVA followed by paired $t$-tests with Bonferroni correction post hoc. Data are presented as mean \pm standard error of the mean. ${ }^{*} P<0.05$ versus control; ${ }^{\text {a }} P<0.05$ versus Sssl.

promoter DNA methylation and decreased expression in female islets (Figure 4B,C and Figure 10), in clonal $\beta$-cells. We also silenced an autosomal gene, BCL11A (Figure 5A, $B$ and Figure 10), that showed decreased DNA methylation and increased expression in female islets in the clonal $\beta$-cells. This resulted in approximately $80 \%, 70 \%$ and $60 \%$ reductions of Nkap, Apln and Bcl11a levels, respectively (Figure 10A-C). Glucose-stimulated insulin secretion at $16.7 \mathrm{mM}$ glucose increased in clonal $\beta$-cells deficient for either Nkap or Apln expression. In addition, basal insulin secretion at $2.8 \mathrm{mM}$ glucose increased in $\beta$-cells deficient for Nkap or Bcl11a expression (Figure 10D,F). Subsequently, the fold change of insulin secretion, calculated as the ratio of secretion at 16.7 over that at $2.8 \mathrm{mM}$ glucose, increased in clonal $\beta$-cells deficient for Apln expression (Figure 10E), while it decreased in cells deficient for Bcl11a (Figure 10G).

\section{Discussion}

This study is, to our knowledge, the first to examine the impact of sex on the genome-wide DNA methylation pattern in humans using the Infinium HumanMethylation450 BeadChip and to describe sex differences in the methylome and transcriptome in human pancreatic islets. We identified both chromosome-wide and site-specific sex differences in DNA methylation on the X chromosome of human pancreatic islets. However, the autosomal chromosomes showed differences in DNA methylation only on the level of individual CpG sites between sexes. Importantly, we also found higher insulin secretion in pancreatic islets from females compared with males, as well as sex differences in gene expression, including microRNAs. Additionally, we did not find any difference in $\beta$-cell number between females and males. This suggests that the difference in insulin secretion could be due to pancreatic islet function rather than a difference in actual $\beta$-cell number. It also suggests that the DNA methylation differences seen between males and females are not due to altered $\beta$-cell composition in the islets.

DNA methylation is known to contribute to $\mathrm{X}$ chromosome inactivation in female mammalian cells [1]. However, in our study males displayed higher average DNA methylation levels in the 3' UTR gene region, as well as in the northern and southern shelves of CpG islands and in the open sea, while females displayed a higher average methylation in the TSS1500, TSS200, 5' UTR, first exon, gene body and intergenic regions as well as in shore regions and the CpG islands. Also, a previous study by Liu et al. [9] identified several CpG sites on the X chromosome with higher DNA methylation levels in cells from saliva from males. In their study they only analyzed DNA methylation in promoter regions, and hence no data on other gene regions was presented. We also found higher DNA methylation of specific CpG sites on the X chromosome in islets from male compared with female donors. Importantly, some of these genes - for example, $A C E 2$, which encodes the Angiotensin I converting enzyme 2 showed lower gene expression in islets from males compared with females. Differential expression of these genes may contribute to metabolic differences between sexes. We could not detect global sex differences for the average degree of DNA methylation on the autosomal chromosomes. However, we found numerous specific $\mathrm{CpG}$ sites on autosomal chromosomes with differences in DNA methylation between the sexes; hence, it seems like the sex differences in DNA methylation on the autosomal chromosomes are gene and/or site-specific rather than global.

Moreover, in this study we identified in total 18 genes on the autosomal chromosomes and 61 genes on the $\mathrm{X}$ chromosome with both differences in DNA methylation 

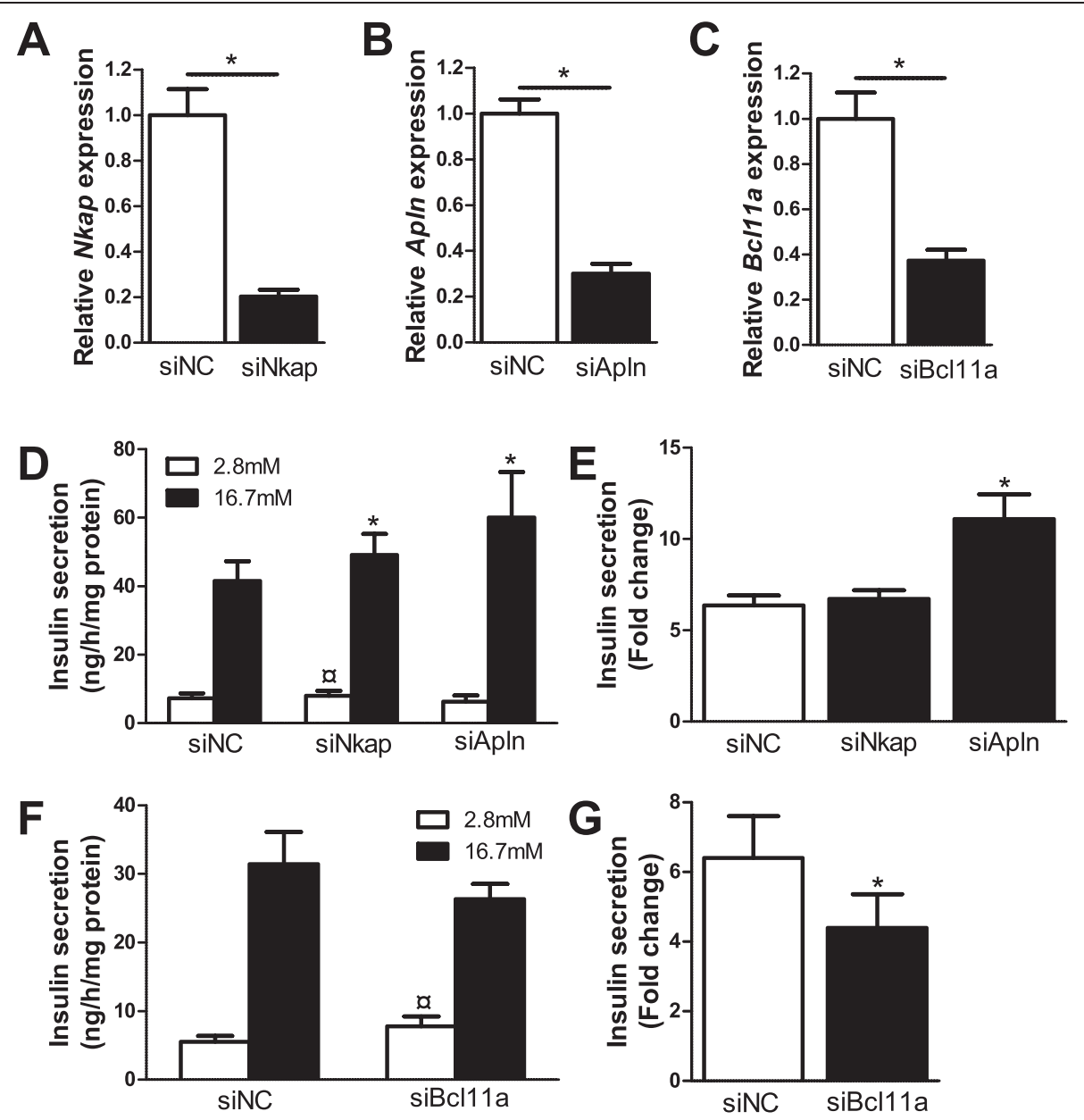

Figure 10 Impact of Nkap, Apln and Bcl11a on insulin secretion in clonal $\beta$-cells. Glucose-sensitive clonal INS-1 832/13 $\beta$-cells were used to study the impact of Nkap, Apln and BCl11a on insulin secretion. (A-C) Transfection of clonal $\beta$-cells with siRNA targeting Nkap, Apln and Bcl11a resulted in decreased Nkap (A), Apln (B) and BCl11a (C) mRNA expression (black bars) when compared with clonal $\beta$-cells transfected with negative control siRNA (siNC, white bar) $(\mathrm{n}=4)$. ${ }^{*} P<0.05$ using a Mann-Whitney test. (D) Insulin secretion in response to $2.8 \mathrm{mM}$ (white bars) and $16.7 \mathrm{mM}$ (black bars) glucose in clonal $\beta$-cells deficient for Nkap $(n=10)$ or Apln $(n=6)$ expression compared with control cells transfected with negative control siRNA (siNC) $(n=10) .{ }^{*} P<0.05$. Also, basal insulin secretion at $2.8 \mathrm{mM}$ glucose showed a slight increase in siNkap-treated cells compared with control ( $\left.{ }^{\mathrm{a}} P=0.049\right)$. (E) Glucose-stimulated insulin secretion presented as the ratio of secretion at 16.7 over that at $2.8 \mathrm{mM}$ glucose (fold change) in clonal $\beta$-cells deficient for Nkap ( $\mathrm{n}=10)$ or Ap/n $(n=6)$ expression (black bars) compared with control cells transfected with negative control siRNA (siNC, white bar) $(n=10)$. (F) Insulin secretion in response to $2.8 \mathrm{mM}$ (white bars) and $16.7 \mathrm{mM}$ (black bars) glucose in clonal $\beta$-cells deficient for $B c / 11 \mathrm{a}(\mathrm{n}=9)$ expression compared with control cells transfected with negative control siRNA (siNC) $(n=9)$. ${ }^{*} P<0.05$. (G) Glucose-stimulated insulin secretion presented as the ratio of secretion at 16.7 over that at $2.8 \mathrm{mM}$ glucose (fold change) in clonal $\beta$-cells deficient for $B c l 11 a(n=9)$ expression (black bars) compared with control cells transfected with negative control siRNA (siNC, white bar) $(n=9)$. ${ }^{*} P<0.05$. The insulin secretion data were normalized to total protein content. Insulin secretion data were analyzed using a Wilcoxon test. Data are presented as mean \pm standard error of the mean.

and gene expression between females and males. These include six genes (for example, APLN, ATF4 and HMGA1) previously known to affect insulin secretion $[33,36,39]$ and 16 genes (for example, ARSD, KDM5C and KIF4A) previously known to contribute to sex differences $[42,46,48]$. To investigate if any of these differences contribute to the lower insulin secretion seen in male compared to female islets, we chose to follow up two $\mathrm{X}$ chromosome genes, $A P L N$ and NKAP, and one autosomal gene, BCL11A, in functional studies. Indeed, silencing of these genes in clonal $\beta$-cells resulted in altered glucose-stimulated insulin secretion.

APLN encodes apelin, a peptide hormone that is widely expressed in several tissues such as the heart and adipose tissue [33,55]. It is also known to be expressed in both human and rodent islets [33]. Previous studies have shown that apelin decreases glucose-stimulated insulin secretion at physiological levels and it was also shown to be expressed at higher levels in pancreatic $\beta$ cells of diabetic animal models compared with wild-type 
animals [33]. Additionally, it has been demonstrated that reduced insulin secretion in the presence of apelin is coupled to reduced levels of cAMP through effects on PDE3B [56]. The results from previous studies are in line with our data, since we found decreased DNA methylation in parallel with increased APLN expression in male islets, which secrete less insulin compared with female islets. Moreover, APLN was previously shown not to escape X-chromosome inactivation [29]. In the present study we also found that silencing of the apelin gene $(A p l n)$ in clonal $\beta$-cells increased glucosestimulated insulin secretion.

NKAP encodes the NF- $\mathrm{kB}$ activating protein, which is a nuclear protein involved in the activation of the transcription of NF-kB [32]. NF-kB is known to positively regulate the transcription of several inflammatory cytokines, such as IL-1 $\beta$, interferon- $\gamma$ and TNF- $\alpha$ [57], which have been shown to decrease glucose-stimulated insulin secretion [58-60]. This could provide a possible mechanism for increased insulin secretion in Nkap silenced cells and in islets that exhibit higher methylation and lower expression of NKAP, for example, female islets. Furthermore, methylation of the NKAP promoter in clonal $\beta$-cells in vitro resulted in decreased transcriptional activity of the reporter gene. This could imply that there is a similar mechanism for transcriptional regulation of NKAP in vivo and that increased DNA methylation contributes to decreased NKAP expression in the human islets. Together, our data suggest that DNA methylation plays a role not only in regulating the differential expression between males and females, but could also be a possible explanation for the differential insulin secretion between sexes. Additionally, NKAP has previously been shown to escape X-chromosome inactivation in a fraction of cells [29].

BCL11A encodes B-cell CLL/lymphoma 11A, a zinc finger protein essential for lymphoid development $[61,62]$ as it controls the expression and activity of $B c l 2$, $B c l 2-x L, M d m 2$ and $\mathrm{p} 53$ and thereby cell survival. Furthermore, knockdown of BCL11A leads to increased rates of apoptosis in lymphoma cell lines [63-65]. Possibly, reduced $B C L 11 A$ expression could also affect survival of other cell types, including $\beta$-cells, and thereby diabetes risk. Indeed, common variants in this gene have previously been associated with an increased risk of type 2 diabetes and with altered pancreatic islet hormone secretion [37,66-68]. Additionally, Tang and co-workers [69] recently showed that blood cells from males with type 2 diabetes had increased methylation of BCL11A compared with healthy male controls. In the present study, we found increased DNA methylation and decreased mRNA expression of BCL11A in male compared with female pancreatic islets. We also found a lower fold change of insulin secretion after silencing Bcl11a in clonal $\beta$-cells, indeed supporting a functional role of this gene in pancreatic $\beta$-cells.
Other identified genes that might help explain the difference in insulin secretion between females and males are ACE2, ATF4 and TFE3. In our study, islet expression of $A C E 2$, which encodes the Angiotensin I converting enzyme 2, was $25 \%$ higher in females than in males and this protein has previously been shown to have positive effects on $\beta$-cell proliferation and insulin secretion $[70,71]$. It was found that pancreatic overexpression of Ace2 in hyperglycemic $d b / d b$ mice resulted in increased insulin secretion while having no effect on insulin sensitivity [70]. Furthermore, islet insulin content and $\beta$-cell mass were also increased and together these changes resulted in a lowered blood glucose in the hyperglycemic $d b / d b$ mice. The expression of ATF4, encoding cyclic AMP-dependent transcription factor ATF4, was higher in male islets and this protein is known to have negative effects on insulin secretion via both direct and indirect effects on the $\beta$-cell [72-74]. Through an interaction with FoxO1 in osteoblasts, ATF4 causes a decrease in circulating levels of the active form of the insulinotropic hormone osteocalcin, which in turn results in a reduction in pancreatic islet number, $\beta$-cell mass and insulin secretion and a worsened glucose tolerance [72,73]. In $\beta$-cells, ATF4 interacts with TRB3 and lowers the expression of key exocytosis genes [74]. Furthermore, the expression of TFE3 was higher in male islets together with differential DNA methylation in several CpG sites connected to this gene. TFE3 encodes transcription factor E3, which is known to stimulate expression of genes downstream of transforming growth factor-beta signaling. Since transforming growth factor-beta singling affects insulin secretion negatively, this could provide a possible mechanism for the lower insulin secretion in males compared with females [75].

Differences in DNA methylation on the X chromosome are expected between males and females. The difference in gene expression found in our study is more surprising. However, it is known that approximately $15 \%$ of all X-chromosome genes consistently escape Xchromosome inactivation and an additional $10 \%$ of these genes show a variable degree of X-chromosome inactivation escape, and may do so in a tissue-specific manner [29]. Subsequently, some of the genes identified in our study may escape $\mathrm{X}$-chromosome inactivation. Indeed, data from Carrel and Willard [29] support the escape of $\mathrm{X}$-chromosome inactivation of some of the genes identified to be differentially methylated in the present study. Additionally, this makes the genes that show differences in both DNA methylation and gene expression between the sexes of interest for further studies in order to fully understand differences between males and females.

Interestingly, we found several $\mathrm{CpG}$ sites annotated to microRNAs with differential DNA methylation between males and females. Two of these microRNAs, hsa-mir-660 
and hsa-miR-532, also showed elevated expression in parallel with decreased DNA methylation in female compared with male islets. Although no previous study has linked these microRNAs to islet function, we found sex differences in islet expression of six target genes for hsa-miR660 and $h s a-m i R-532$ (for example, XPOT and SPIRE1). Furthermore, studies have shown a sex-specific response to different pathological conditions and it has been discussed whether microRNAs could play a role in this sexspecific response [76]. However, to our knowledge, this is the first study showing sex differences in DNA methylation and expression of microRNAs together with target genes in human pancreatic islets.

When specifically analyzing if candidate genes for type 2 diabetes and related metabolic traits showed any differences in DNA methylation between sexes, we found that 10 of the type 2 diabetes candidate genes and 7 of the type 2 diabetes trait candidate genes had significant differences in DNA methylation between males and females. Several of these genes (for example, HNF4A and CDKN2B) have been proposed to be associated with pancreatic islet function $[38,77]$ and it is hence possible that they contribute to sex differences in islets function.

It is important to be aware that the Infinium HumanMethylation450 BeadChip array includes probes with cross-reactivity to other sites in the genome [23,78]. This presents a particular difficulty when studying sex differences with autosomal probes that possibly could crossreact to the $\mathrm{X}$ or $\mathrm{Y}$ chromosome. However, in this study we only found a few cross-reactive probes with a perfect match to another genomic location.

\section{Conclusion}

Our study has identified both chromosome-wide and genespecific sex differences in DNA methylation on the $\mathrm{X}$ chromosome of human pancreatic islets, whereas the autosomal chromosomes only showed site-specific differences. These epigenetic differences were associated with differential gene expression, microRNA levels and insulin secretion in human pancreatic islets. Our functional studies further support that altered expression of these genes might explain secretory differences in vivo.

\section{Materials and methods}

\section{Human pancreatic donors}

Pancreatic islets from 87 deceased non-diabetic donors were obtained from the human tissue laboratory at Lund University Diabetes Centre (Table 1). Only islets from non-diabetic individuals with an $\mathrm{HbA1c}$ below 6.5\% were included in this study. HbA1c was measured using the mono-s method [79]. Islets were prepared by collagenase digestion and density gradient purifications and they were cultured for $4 \pm 2$ days as previously described prior to DNA and RNA extraction
[80]. The purity of the islet preparations was determined by dithizone staining.

Glucose-stimulated insulin secretion, calculated as SI, from the human islets was measured in vitro in static incubations as previously described [21]. Maximum and minimum SI values were set to 1 and 30, respectively, since this is more biologically relevant [21]. Informed consent for organ donation for medical research was obtained from pancreatic donors or their relatives in accordance with the approval by the regional ethics committee in Lund, Sweden (Dnr 173/2007). This study was performed in agreement with the Helsinki Declaration and in adherence to the regulations of the regional ethics committee.

\section{Calculating $\beta$-cell content}

$\beta$-cell content in human islets of donors with available embedded islets (six male and seven female donors) was analyzed using transmission electron microscopy. Hand-picked islets were fixed in $2.5 \%$ glutaraldehyde in freshly prepared Millonig and post-fixed in 1\% osmium tetroxide before being dehydrated and embedded in AGAR 100 (Oxford Instruments Nordiska, Lidingö, Sweden) and cut into ultrathin sections as previously described [81]. The sections were put on $\mathrm{Cu}$-grids and contrasted using uranyl acetate and lead citrate. The islet-containing sections were examined in a JEM 1230 electron microscope (JEOL-USA. Inc., Peabody, MA, USA). Micrographs were analyzed for $\beta$-cell content using Image and in-house software programmed in Matlab with methods previously described [82,83]. Islet cell types were distinguished by means of granular appearance: $\beta$-cell granules have a dense core surrounded by a white halo and $\alpha$-cells have smaller dense granules lacking a distinguished halo. The ratio of $\beta$-cells in each islet was calculated by division of the total number of $\beta$-cells by the sum of the $\beta$-cell and $\alpha$-cell numbers.

\section{DNA and RNA extraction}

DNA and RNA were extracted from human pancreatic islets using the AllPrep DNA/RNA kit (Qiagen, Hilding, Germany) according to the manufacturer's instructions. Nucleic acid purity and concentration were determined using a nanodrop (NanoDrop Technologies, Wilmington, DE, USA). All DNA samples had an A260/280 ratio of 1.8 to 2.1 , whereas the $260 / 280$ ratios for RNA were 1.9 to 2.2. The integrity and quality of the RNA were assessed using the Bioanalyzer (Agilent Technologies, Santa Clara, CA, USA) and available RNA integrity number (RIN) values from the Bioanalyzer were between 8.6 and 10 .

\section{Genome-wide DNA methylation analysis of human pancreatic islets}

Genome-wide DNA methylation analysis of human pancreatic islets was performed at the SCIBLU genomics centre at Lund University with the Infinium HumanMethylation450 
BeadChip kit (Illumina, Inc., CA, USA). Genomic DNA (500 ng) was bisulfite converted using an EZ DNA methylation kit (Zymo Research, Orange, CA, USA). The total amount of bisulfite converted DNA was used to analyze DNA methylation with Infinium assay using the standard Infinium HD Assay Methylation Protocol Guide (part number 15019519, Illumina). The bead chips were imaged using the Illumina iScan. The Infinium HumanMethylation450 BeadChip contains 485,577 probes out of which 3,091 are so-called non-CpG probes, and covers $99 \%$ of all RefSeq genes with the capacity for 12 samples per chip [22]. No probes on the chip are designed to target the pseudoautosomal region of the $\mathrm{X}$ chromosome, as these probes would not be unique. The GenomeStudio ${ }^{\circ}$ methylation module software was used to calculate the raw methylation score for each DNA methylation site, which is presented as methylation $\beta$-value. The $\beta$-values are calculated as $\beta=$ Intensity of the methylated allele $(\mathrm{M}) /($ Intensity of the unmethylated allele $(\mathrm{U})+$ Intensity of the methylated allele $(\mathrm{M})+100)$. All samples passed GenomeStudio quality control steps based on built-in control probes for staining, hybridization, extension and specificity and displayed high quality bisulfite conversion efficiency with an intensity signal above 4,000 [84]. Probes were then filtered based on Illumina detection $P$-value, and probes with a mean detection $P$-value $>0.01$ were removed from further analysis. In total, DNA methylation data were obtained for 483,031 probes out of which 3,039 probes are non-CpG sites. Since the cohort included islets from both males and females, Ychromosome data were removed and subsequently DNA methylation data from 482,954 probes remained for further analysis. $\beta$-values were converted to $\mathrm{M}$-values for further analysis $(M=\log 2(\beta /(1-\beta))$ [85] to remove heteroscedasticity in the data distribution. Background correction and quantile normalization were performed using the lumi package from bioconductor [86]. The methylation data were then separated on autosomal chromosomes and $\mathrm{X}$ chromosome before further analysis.

To identify differences in DNA methylation between males and females, the methylation data were analyzed using a linear regression model with the limma package in Bioconductor $[87,88]$ including batch, age, BMI, purity of the islets, days in culture and $\mathrm{HbA1c}$ as covariates.

A FDR analysis was performed to correct $P$-values for multiple testing and $q$-values $<0.05$ were considered significant. In order to further test which factors affect the DNA methylation level in our dataset, we performed a principal component analysis of the DNA methylation data and correlated the top principal component with sex and all covariates of interest, including age, BMI, purity of the islets, days in culture and HbAa1c as described in [84]. Here, only sex and BMI showed significant correlations with the first principal component $\left(P=6.8 \times 10^{-3}\right.$ and $P=0.03$, respectively). Since $\beta$-values are easier to interpret biologically, $M$-values were reconverted into $\beta$-values and were then used when describing the data and when generating figures. Non-CpG probes are presented with probe ID starting with 'ch' (Additional files 2, 3, 4, 5, 15, 16, 17, and 18). Moreover, since some probes on Illumina's DNA methylation chip may cross-react to multiple locations in the genome, we used the published data by Chen et al. [23] to evaluate the number of possible cross-reactive probes among our significant methylation data (Additional files 6 and 7).

\section{mRNA expression analysis of human pancreatic islets}

mRNA expression was analyzed using Affymetrix GeneChip Human Gene 1.0 ST whole transcript based array (Affymetrix, Santa Clara, CA, USA) according to the manufacturer's recommendations. We computed Robust Multichip Average (RMA) expression measure using the oligo package from Bioconductor [89]. To identify differences in gene expression between males and females, the data were analyzed using a linear regression model with the limma package in Bioconductor $[87,88]$ with age, BMI, purity of the islets, days in culture, and HbA1c as covariates. We also performed a principal component analysis of the mRNA expression data and correlated the top principal component with sex and all covariates of interest, including age, BMI, purity of the islets, days in culture and HbAa1c as described in [84]. Here, purity of the islets showed significant correlations with the first principal component $(P=0.020)$, while sex and HbA1c showed significant correlations with the second principle component $(P=0.036$ and $P=0.034)$.

\section{Locked nucleic acid-based microarray of human microRNAs}

RNA from hand-picked human islets was extracted from four male and seven female donors using a miRNeasy kit (Qiagen). RNA quantity and quality were evaluated using spectrophotometry by Nanodrop and electropherogram profiles by Experion (BioRad, Hercules, CA, USA), respectively. Total RNA (500 ng) was directly labeled with miRCURY Hy3 fluorescent dye, which was subsequently hybridized to miRCURY LNA microRNA array v.11.0 in a Maui hybridization chamber according to the manufacturer's recommendations (Exiqon, Vedbaek, Denmark). Images were acquired using Agilent array scanner and spot intensities were quantified in Genepix Pro 4.1. Array signals were normalized using the global Lowess regression algorithm as implemented in CARMAweb 1.4 [90]. For this study, only array signals from microRNAs within genomic loci showing differential methylation patterns were considered in the analysis.

\section{Validation of DNA methylation array results}

Technical validation of the Infinium HumanMethylation450 BeadChip methylation data was performed by 
PyroSequencing (Qiagen) of three selected CpG sites (cg27483305, cg05688478, and cg13808071). Pre-designed PyroSequencing assays (PCR primers and sequencing primer) were used for the selected CpG sites (Qiagen) (Additional file 23). PyroSequencing was performed with the PyroMark ${ }^{\mathrm{m}} \mathrm{Q} 96$ ID system (Qiagen) and all procedures were performed according to the manufacturer's recommendations. In short, 500 ng genomic DNA from pancreatic islet of 50 human donors (32 males, 18 females) was bisulfite converted using EpiTect Bisulfite Kit (Qiagen), and $10 \mathrm{ng}$ bisulfite converted DNA was then used as input for each PCR assay. Furthermore, PyroMark PCR Master Mix kit (Qiagen), streptavidin coated beads (GE Healthcare, Uppsala, Sweden), PyroMark Gold Q96 reagents (Qiagen) and PyroMark Q96 (version 2.5.8) software (Qiagen) were used for the analysis of DNA methylation, all according to the manufacturers' recommendations.

\section{Luciferase assay}

The luciferase assay protocol has been described in detail elsewhere [91]. Briefly, a 1,500 bp fragment of the NKAP or SPESP1 promoter (Additional file 24) covering CpG sites that exhibited differential DNA methylation in female versus male islets (Figure 4) was cloned into a CpG-free luciferase reporter vector (pCpGL-basic) kindly provided by Dr Klug and Dr Rehli [92]. Amplification of the NKAP and SPESP1 sequences and insertion into the PCPGL basic vector was performed by GenScript (GenScript USA Inc., Piscataway, NJ, USA). Two different DNA methyltransferases, SssI and

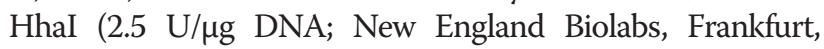
Germany), were then used to methylate the constructs. SssI methylates all cytosine residues within the double-stranded dinucleotide recognition sequence CG and HhaI methylates only the internal cytosine residue in the GCGC sequence. The clonal rat $\beta$-cell line INS 832/13 was cultured as described [93], and co-transfected with $100 \mathrm{ng}$ methylated or mock-methylated $\mathrm{pCpGL}$ vector including either the NKAP or SPESP1 promoter insert together with $4 \mathrm{ng}$ of pRL renilla luciferase control reporter vector (Promega, Madison, WI, USA). Firefly and renilla luciferase luminescence, as a value of transcriptional activity, was measured for each construct with the Dual-Glo Luciferase Assay System (Promega) and an Infinite ${ }^{\circ} 200$ PRO multiplate reader (Tecan Group Ltd, Männedorf, Switzerland). The result represents the mean of at least five independent experiments, and the results of each experiment are the mean of five replicates. Cells transfected with an empty pCpGL vector were used as background control for the firefly luciferase results, and untransfected cells were used as a background for the renilla results.

\section{RNA interference of Apln, Nkap and Bcl11a in clonal $\beta$-cells}

Three genes selected from the DNA methylation and mRNA expression analyses were silenced in clonal INS-1
832/13 $\beta$-cells [93] by siRNA transfection with Dharmafect I (Thermo Scientific, Waltham, MA, USA) according to the manufacturer's instructions. The siRNAs (LifeTechnologies, Paisley, UK) used were s132851 (Apln), s151310 (Nkap), s156923 (Bcl11a) and a negative control siRNA (5'GAGACCCUAUCCGUGAUUAUU-3'). RNA was isolated $72 \mathrm{~h}$ post-transfection with the RNeasy Plus mini kit (Qiagen) and subsequently converted to cDNA with the RevertAid First Strand cDNA Synthesis kit (Thermo Scientific). Knockdown was verified by quantitative PCR with the following TaqMan assays (Life Technologies); Rn0058109 3_m1 (Apln), Rn01297610_m1 (Nkap) and Rn014340 83_m1 (Bcl11a). Ppib (Cyclophilin B; Rn03302274_m1) and Hprt1 (Rn01527840_m1) were used as endogenous controls and quantification was done with the $\Delta \Delta \mathrm{Ct}$ method.

\section{Insulin secretion}

Insulin secretion was determined during $1 \mathrm{~h}$ static incubations $72 \mathrm{~h}$ post-transfection of clonal INS-1 832/13 $\beta$ cells with siRNA against Apln, Nkap or Bcl11a. Prior to analysis of insulin secretion, clonal $\beta$-cells in multi-well plates were washed in HEPES balanced salt solution (HBSS; $114 \mathrm{mM} \mathrm{NaCl}, 4.7 \mathrm{mM} \mathrm{KCl}, 1.2 \mathrm{mM} \mathrm{KH}_{2} \mathrm{PO}_{4}$, $1.16 \mathrm{mM} \mathrm{MgSO}_{4}, 20 \mathrm{mM}$ HEPES, $2.5 \mathrm{mM} \mathrm{CaCl}_{2}, 25.5$ $\mathrm{mM} \mathrm{NaHCO} 3,0.2 \%$ bovine serum albumin, $\mathrm{pH}$ 7.2) supplemented with $2.8 \mathrm{mM}$ glucose and pre-incubated for 2 $\mathrm{h}$ at $37^{\circ} \mathrm{C}$. Insulin secretion was then measured by static incubation for $1 \mathrm{~h}$ in $1.0 \mathrm{ml}$ HBSS containing 2.8 or 16.7 $\mathrm{mM}$ glucose. Released insulin was determined with the Coat-a-Count Kit (Siemens Diagnostics, Erlangen, Germany) and normalized to the amount of protein in each well as measured with the BCA Protein Assay Kit (Thermo Scientific).

\section{Data availability}

The Gene Expression Omnibus accession numbers for the methylation and expression array data reported in this paper are GSE62640 and GSE54279, respectively.

\section{Statistics}

Unsupervised hierarchical clustering was performed with batch-corrected DNA methylation array data and calculated using the R software [94]. All data are presented as mean \pm standard deviation unless stated otherwise. Phenotype data presented in the text or in Table 1 were calculated using a Mann-Whitney test in IBM SPSS statistics 20.0 (IBM Corp., released 2011, IBM SPSS Statistics for Windows, Version 20.0, Armonk, NY, USA).

\section{Additional files}

Additional file 1: Sex does not affect the relative $\beta$-cell number in human pancreatic islets. Analysis of $\beta$-cell number with transmission electron microscopy showed no difference between male and female 
human pancreatic islets. $P=0.29$ based on a Mann-Whitney $U$ test. Data are presented as mean \pm standard error of the mean.

Additional file 2: Autosomal DNA methylation data $(q<0.05$, delta $\beta$-value $>5 \%$ ) with higher methylation levels in female compared with male islets. Excel file showing significant DNA methylation sites with FDR less than $5 \%$ and absolute sex differences in DNA methylation bigger than $5 \%$.

Additional file 3: Autosomal DNA methylation data $(q<0.05$, delta $\beta$-value $>5 \%$ ) with higher methylation levels in male compared with female islets. Excel file showing significant DNA methylation sites with FDR less than $5 \%$ and absolute sex differences in DNA methylation bigger than $5 \%$.

Additional file 4: $X$ chromosome DNA methylation data $(q<0.05$, delta $\beta$-value $>5 \%$ ) with higher methylation levels in female compared with male islets. Excel file showing significant DNA methylation sites with FDR less than $5 \%$ and absolute sex differences in DNA methylation bigger than $5 \%$.

Additional file 5: $X$ chromosome DNA methylation data $(q<0.05$, delta $\beta$-value $>5 \%$ ) with higher methylation levels in male compared with female islets. Excel file showing significant DNA methylation sites with FDR less than $5 \%$ and absolute sex differences in DNA methylation bigger than $5 \%$.

Additional file 6: Cross-reactive probes for autosomal chromosomes only. Autosomal chromosome probes showing differential DNA methylation in human islets based on sex $(a<0.05$, delta $\beta$-value $>5 \%)$ and with possible cross-reactivity to other locations in the genome. The map info is based on genome build 37. BLAT chromosome position, BLAT coordinates and numbers of matching base pairs are based on previously published data [23]. Of note, some probes cross-react to more than one location in the genome.

Additional file 7: Cross-reactive probes for $\mathrm{X}$ chromosome only. $\mathrm{X}$ chromosome probes showing differential DNA methylation in human islets based on sex $(a<0.05$, delta $\beta$-value $>5 \%)$ and with possible cross-reactivity to other locations in the genome. The map info is based on genome build 37. BLAT coordinates and numbers of matching base pairs are based on previously published data [23]. Of note, some probes cross-react to more than one location in the genome.

Additional file 8: Sites on the autosomal chromosomes where DNA methylation significantly associates with both pancreatic islet purity and sex. Autosomal data where DNA methylation is significantly associated with both sex and the co-variate islet purity $(q<0.05)$.

Additional file 9: Sites on the $X$ chromosome where DNA methylation significantly associates with both pancreatic islet purity and sex. X-chromosome data where DNA methylation is significantly associated with both sex and the co-variate islet purity $(q<0.05)$.

Additional file 10: KEGG pathway analysis result. Results from KEGG pathway analysis of genes with differential methylation in males and females for the autosomal chromosome genes.

Additional file 11: Candidate genes for type 2 diabetes that exhibit differential DNA methylation in human pancreatic islets based on sex. Excel file showing individual CpG sites located within/near candidate genes for type 2 diabetes [28], with a significant difference $(q<0.05)$ in DNA methylation in human pancreatic islets between females and males.

Additional file 12: Candidate genes for type 2 diabetes-related traits that exhibit differential DNA methylation in human pancreatic islets based on sex. Excel file showing individual CpG sites located within/near candidate genes for type 2 diabetes-related traits [28], with a significant difference $(q<0.05)$ in DNA methylation in human pancreatic islets between females and males.

Additional file 13: $X$ chromosome inactivation status of genes with sites that are more methylated in pancreatic islets from female compared with male donors. Our significant methylation data were compared to data published by Carrel and Willard [29], where they studied the expression status of genes on the inactivated $X$ chromosome in a fibroblast-based system. The list contains genes with sites that are more methylated in islets from female compared with male donors, separated into genes that do not or do, partially or completely, escape X chromosome inactivation based on the data by Carrel and Willard.
Additional file 14: $X$ chromosome inactivation status of genes with sites that are more methylated in pancreatic islets from male compared with female donors. Our significant methylation data were compared to data published by Carrel and Willard [29] where they studied the expression status of genes on the inactivated $X$ chromosome in a fibroblast-based system. The list contains genes with sites that are more methylated in islets from male compared with female donors, separated into genes that do not or do, partially or completely, escape X chromosome inactivation based on the data by Carrel and Willard.

Additional file 15: DNA methylation differences and expression differences in autosomal genes based on sex. Excel file showing genes exhibiting both significantly higher DNA methylation in females compared to males ( $q<0.05$, delta $\beta$-value $>5 \%$ ) as well as differential mRNA expression at $p<0.05$ in human pancreatic islets, for autosomal genes only.

Additional file 16: DNA methylation differences and expression differences in autosomal genes based on sex. Excel file showing genes exhibiting both significantly higher DNA methylation in males compared with females $(q<0.05$, delta $\beta$-value $>5 \%)$ as well as differential mRNA expression at $P<0.05$ in human pancreatic islets, for autosomal genes only.

Additional file 17: DNA methylation differences and expression differences in X-chromosome genes based on sex. Excel file showing genes exhibiting both significantly higher DNA methylation in females compared with males $(q<0.05$, delta $\beta$-value $>5 \%)$ as well as differential mRNA expression at $P<0.05$ in human pancreatic islets, for $X$-chromosome genes only

Additional file 18: DNA methylation differences and expression differences in X-chromosome genes based on sex. Excel file showing genes exhibiting both significantly higher DNA methylation in males compared with females $(q<0.05$, delta $\beta$-value $>5 \%)$ as well as differential mRNA expression at $P<0.05$ in human pancreatic islets, for $X$-chromosome genes only.

Additional file 19: Target genes for hsa-miR-660. Excel file showing potential target genes of hsa-miR-660 generated using TargetScan Human release 6.2 (June 2012) [53].

Additional file 20: Target genes for $\boldsymbol{h s a}$ a-miR-532. Excel file showing potential target genes of hsa-miR-532 generated using TargetScan Human release 6.2 (June 2012) [53].

Additional file 21: Differentially expressed target genes of $h s a-m i R-660$ and $\boldsymbol{h} s \boldsymbol{a}-\mathbf{m i R}-\mathbf{5 3 2}$. Excel file showing the differentially expressed target genes of hsa-miR-660 and hsa-miR-532 between female and male human islets.

Additional file 22: Putative transcription factor binding sites in the SPESP1 promoter. List of transcription factors with known repressive effect and putative binding sites in the SPESP1 promoter.

Additional file 23: Assay information for technical validation of the Infinium HumanMethylation450 BeadChip (Illumina) DNA methylation data. Table showing the assays used for technical validation of the Infinium HumanMethylation450 BeadChip (Illumina) using pre-designed PyroSequencing (Qiagen) assays. Position is based on genome build 37.

Additional file 24: Sequences for the NKAP and SPESP1 promoters used for luciferase assay. We cloned 1,500 bp fragments of the NKAP and SPESP1promoters covering CpG sites that exhibited differential DNA methylation in female versus male islets into a CpG-free luciferase reporter vector for the luciferase assay.

\section{Abbreviations}

BMI: body mass index; bp: base pair; FDR: false discovery rate; GWAS: genome-wide association study; HbA1c: hemoglobin A1c; HBSS: HEPES balanced salt solution; KEGG: Kyoto Encyclopedia of Genes and Genomes; Sl: stimulation index; siRNA: small interfering RNA; SNP: single nucleotide polymorphism; TSS: transcription start site; UTR: untranslated region.

\section{Competing interests}

The authors declare that they have no competing interests. 


\section{Authors' contributions}

EH designed and conducted the study, performed lab work, collected, analyzed and interpreted data and wrote the manuscript. PV designed and conducted the study, analyzed and interpreted data and reviewed and edited the manuscript. TD analyzed data and reviewed and edited the manuscript. JLSE performed lab work, analyzed and interpreted data and reviewed and edited the manuscript. SS performed lab work, analyzed and interpreted data and reviewed and edited the manuscript. LE performed lab work, analyzed and interpreted data and reviewed and edited the manuscript. TR interpreted data and reviewed and edited the manuscript. KB performed lab work, analyzed and interpreted data and reviewed and edited the manuscript. CL designed and conducted the study, analyzed and interpreted data and reviewed and edited the manuscript. EH and $\mathrm{CL}$ are guarantors of this work and, as such, had full access to all of the data in the study and take responsibility for the integrity of the data. All authors read and approved the final manuscript.

\section{Acknowledgements}

We thank SCIBLU at Lund University for analyzing gene expression. We thank the Nordic Network for Clinical Islet Transplantation (JDRF award 31-2008-413), the tissue isolation teams, Human Tissue Laboratory within EXODIAB/Lund University Diabetes Centre and technical assistance from Britt-Marie Nilsson and Rita Wallen. This work was supported by grants from the Swedish Research Council, Crafoord Foundation, Region Skåne, Knut and Alice Wallenberg Foundation, Novo Nordisk foundation, EFSD/Lilly Fellowship, Söderberg foundation, The Swedish Diabetes foundation, Påhlsson foundation, EXODIAB and Linné grant (B31 5631/2006).

\section{Author details}

'Epigenetics and Diabetes Unit, Department of Clinical Sciences, Lund University Diabetes Centre, CRC, Lund University, Scania University Hospital, 20502 Malmö, Sweden. ${ }^{2}$ Islet Cell Exocytosis, Department of Clinical Sciences, Lund University Diabetes Centre, Lund University, CRC, 20502 Malmö, Sweden.

Received: 10 April 2014 Accepted: 30 October 2014 Published online: 03 December 2014

\section{References}

1. Jirtle RL, Skinner MK: Environmental epigenomics and disease susceptibility. Nat Rev Genet 2007, 8:253-262.

2. Lister R, Pelizzola M, Kida YS, Hawkins RD, Nery JR, Hon G, AntosiewiczBourget J, O'Malley R, Castanon R, Klugman S, Downes M, Yu R, Stewart R, Ren B, Thomson JA, Evans RM, Ecker JR: Hotspots of aberrant epigenomic reprogramming in human induced pluripotent stem cells. Nature 2011, 471:68-73.

3. Sarter B, Long TI, Tsong WH, Koh WP, Yu MC, Laird PW: Sex differential in methylation patterns of selected genes in Singapore Chinese. Hum Genet 2005, 117:402-403.

4. Eckhardt F, Lewin J, Cortese R, Rakyan VK, Attwood J, Burger M, Burton J, Cox TV, Davies R, Down TA, Haefliger C, Horton R, Howe K, Jackson DK, Kunde J, Koenig C, Liddle J, Niblett D, Otto T, Pettett R, Seemann S, Thompson C, West T, Rogers J, Olek A, Berlin K, Beck S: DNA methylation profiling of human chromosomes 6, 20 and 22. Nat Genet 2006, 38:1378-1385

5. El-Maarri O, Becker T, Junen J, Manzoor SS, Diaz-Lacava A, Schwaab R, Wienker T, Oldenburg J: Gender specific differences in levels of DNA methylation at selected loci from human total blood: a tendency toward higher methylation levels in males. Hum Genet 2007, 122:505-514.

6. Boks MP, Derks EM, Weisenberger DJ, Strengman E, Janson E, Sommer IE, Kahn RS, Ophoff RA: The relationship of DNA methylation with age, gender and genotype in twins and healthy controls. PLoS One 2009, 4:e6767.

7. Cotton AM, Lam L, Affleck JG, Wilson IM, Penaherrera MS, McFadden DE, Kobor MS, Lam WL, Robinson WP, Brown CJ: Chromosome-wide DNA methylation analysis predicts human tissue-specific $\mathrm{X}$ inactivation. Hum Genet 2011, 130:187-201.

8. Hellman A, Chess A: Gene body-specific methylation on the active $X$ chromosome. Science 2007, 315:1141-1143.

9. Liu J, Morgan M, Hutchison K, Calhoun VD: A study of the influence of sex on genome wide methylation. PLoS One 2010, 5:e10028.
10. Brenet F, Moh M, Funk P, Feierstein E, Viale AJ, Socci ND, Scandura JM: DNA methylation of the first exon is tightly linked to transcriptional silencing. PLoS One 2011, 6:e14524.

11. Aran D, Toperoff G, Rosenberg M, Hellman A: Replication timing-related and gene body-specific methylation of active human genes. Hum Mol Genet 2011, 20:670-680.

12. Irizarry RA, Ladd-Acosta C, Wen B, Wu Z, Montano C, Onyango P, Cui H, Gabo K, Rongione M, Webster M, Ji H, Potash JB, Sabunciyan S, Feinberg AP: The human colon cancer methylome shows similar hypo- and hypermethylation at conserved tissue-specific CpG island shores. Nat Genet 2009, 41:178-186.

13. Ball MP, Li JB, Gao Y, Lee JH, LeProust EM, Park IH, Xie B, Daley GQ, Church GM: Targeted and genome-scale strategies reveal gene-body methylation signatures in human cells. Nat Biotechnol 2009, 27:361-368.

14. Rauch TA, Wu X, Zhong X, Riggs AD, Pfeifer GP: A human B cell methylome at 100-base pair resolution. Proc Natl Acad Sci U S A 2009, 106:671-678.

15. Lister R, Pelizzola M, Dowen RH, Hawkins RD, Hon G, Tonti-Filippini J, Nery JR, Lee L, Ye Z, Ngo QM, Edsall L, Antosiewicz-Bourget J, Stewart R, Ruotti V, Millar AH, Thomson JA, Ren B, Ecker JR: Human DNA methylomes at base resolution show widespread epigenomic differences. Nature 2009, 462:315-322.

16. Ronn T, Volkov P, Davegardh C, Dayeh T, Hall E, Olsson AH, Nilsson E, Tornberg A, Dekker Nitert M, Eriksson KF, Jones HA, Groop L, Ling C: A six months exercise intervention influences the genome-wide DNA methylation pattern in human adipose tissue. PLoS Genet 2013, 9:e1003572.

17. Clausen JO, Borch-Johnsen K, lbsen H, Bergman RN, Hougaard P, Winther K, Pedersen O: Insulin sensitivity index, acute insulin response, and glucose effectiveness in a population-based sample of 380 young healthy Caucasians. Analysis of the impact of gender, body fat, physical fitness, and life-style factors. J Clin Invest 1996, 98:1195-1209.

18. Basu R, Dalla Man C, Campioni M, Basu A, Klee G, Toffolo G, Cobelli C, Rizza RA: Effects of age and sex on postprandial glucose metabolism: differences in glucose turnover, insulin secretion, insulin action, and hepatic insulin extraction. Diabetes 2006, 55:2001-2014.

19. Kautzky-Willer A, Brazzale AR, Moro E, Vrbikova J, Bendlova B, Sbrignadello S, Tura A, Pacini G: Influence of increasing BMI on insulin sensitivity and secretion in normotolerant men and women of a wide age span. Obesity (Silver Spring) 2012, 20:1966-1973.

20. Magkos F, Wang $X$, Mittendorfer B: Metabolic actions of insulin in men and women. Nutrition 2010, 26:686-693.

21. Stahle MU, Brandhorst D, Korsgren O, Knutson F: Pathogen inactivation of human serum facilitates its clinical use for islet cell culture and subsequent transplantation. Cell Transplant 2011, 20:775-781.

22. Bibikova M, Barnes B, Tsan C, Ho V, Klotzle B, Le JM, Delano D, Zhang L, Schroth GP, Gunderson KL, Fan JB, Shen R: High density DNA methylation array with single CpG site resolution. Genomics 2011, 98:288-295.

23. Chen YA, Lemire M, Choufani S, Butcher DT, Grafodatskaya D, Zanke BW, Gallinger S, Hudson TJ, Weksberg R: Discovery of cross-reactive probes and polymorphic CpGs in the Illumina Infinium HumanMethylation450 microarray. Epigenetics 2013, 8:203-209.

24. Wang J, Duncan D, Shi Z, Zhang B: WEB-based GEne SeT AnaLysis Toolkit (WebGestalt): update 2013. Nucleic Acids Res 2013, 41:W77-W83.

25. Zhang B, Kirov S, Snoddy J: WebGestalt: an integrated system for exploring gene sets in various biological contexts. Nucleic Acids Res 2005, 33:W741-W748.

26. Randall JC, Winkler TW, Kutalik Z, Berndt SI, Jackson AU, Monda KL, Kilpelainen TO, Esko T, Magi R, Li S, Workalemahu T, Feitosa MF, CroteauChonka DC, Day FR, Fall T, Ferreira T, Gustafsson S, Locke AE, Mathieson I, Scherag A, Vedantam S, Wood AR, Liang L, Steinthorsdottir V, Thorleifsson G, Dermitzakis ET, Dimas AS, Karpe F, Min JL, Nicholson G, et al: Sexstratified genome-wide association studies including 270,000 individuals show sexual dimorphism in genetic loci for anthropometric traits. PLoS Genet 2013, 9:e1003500.

27. Lindgren CM, Heid IM, Randall JC, Lamina C, Steinthorsdottir V, Qi L, Speliotes EK, Thorleifsson G, Willer CJ, Herrera BM, Jackson AU, Lim N, Scheet P, Soranzo N, Amin N, Aulchenko YS, Chambers JC, Drong A, Luan J, Lyon HN, Rivadeneira F, Sanna S, Timpson NJ, Zillikens MC, Zhao JH, Almgren P, Bandinelli S, Bennett AJ, Bergman RN, Bonnycastle LL, et al: Genome-wide association scan meta-analysis identifies three Loci influencing adiposity and fat distribution. PLoS Genet 2009, 5:e1000508. 
28. Hindorff LA, Sethupathy P, Junkins HA, Ramos EM, Mehta JP, Collins FS, Manolio TA: Potential etiologic and functional implications of genomewide association loci for human diseases and traits. Proc Natl Acad Sci U S A 2009, 106:9362-9367.

29. Carrel L, Willard HF: X-inactivation profile reveals extensive variability in X-linked gene expression in females. Nature 2005, 434:400-404.

30. Ling C, Groop L: Epigenetics: a molecular link between environmental factors and type 2 diabetes. Diabetes 2009, 58:2718-2725.

31. Jones PA: Functions of DNA methylation: islands, start sites, gene bodies and beyond. Nat Rev Genet 2012, 13:484-492.

32. Chen D, Li Z, Yang Q, Zhang J, Zhai Z, Shu HB: Identification of a nuclear protein that promotes NF-kappaB activation. Biochem Biophys Res Commun 2003, 310:720-724.

33. Ringstrom $C$, Nitert MD, Bennet $H$, Fex M, Valet $P$, Rehfeld JF, Friis-Hansen $L$, Wierup N: Apelin is a novel islet peptide. Regul Pept 2010, 162:44-51.

34. Wolkowicz MJ, Digilio L, Klotz K, Shetty J, Flickinger CJ, Herr JC: Equatorial segment protein (ESP) is a human alloantigen involved in sperm-egg binding and fusion. $J$ Androl 2008, 29:272-282.

35. Niu MJ, Yang JK, Lin SS, Ji XJ, Guo LM: Loss of angiotensin-converting enzyme 2 leads to impaired glucose homeostasis in mice. Endocrine 2008, 34:56-61.

36. Hinoi E, Gao N, Jung DY, Yadav V, Yoshizawa T, Kajimura D, Myers MG Jr, Chua SC Jr, Wang Q, Kim JK, Kaestner KH, Karsenty G: An Osteoblast-dependent mechanism contributes to the leptin regulation of insulin secretion. Ann N Y Acad Sci 2009, 1173:E20-E30.

37. Simonis-Bik AM, Nijpels G, van Haeften TW, Houwing-Duistermaat JJ, Boomsma DI, Reiling E, van Hove EC, Diamant M, Kramer MH, Heine RJ, Maassen JA, Slagboom PE, Willemsen G, Dekker JM, Eekhoff EM, de Geus EJ, t Hart LM: Gene variants in the novel type 2 diabetes loci CDC123/ CAMK1D, THADA, ADAMTS9, BCL11A, and MTNR1B affect different aspects of pancreatic beta-cell function. Diabetes 2010, 59:293-301.

38. Hribal ML, Presta I, Procopio T, Marini MA, Stancakova A, Kuusisto J, Andreozzi F, Hammarstedt A, Jansson PA, Grarup N, Hansen T, Walker M, Stefan N, Fritsche A, Haring HU, Pedersen O, Smith U, Laakso M, Sesti G: Glucose tolerance, insulin sensitivity and insulin release in European non-diabetic carriers of a polymorphism upstream of CDKN2A and CDKN2B. Diabetologia 2011, 54:795-802.

39. Foti D, Chiefari E, Fedele M, luliano R, Brunetti L, Paonessa F, Manfioletti G, Barbetti F, Brunetti A, Croce CM, Fusco A: Lack of the architectural factor HMGA1 causes insulin resistance and diabetes in humans and mice. Nat Med 2005, 11:765-773.

40. Gupte M, Thatcher SE, Boustany-Kari CM, Shoemaker R, Yiannikouris F, Zhang $X$, Karounos M, Cassis LA: Angiotensin converting enzyme 2 contributes to sex differences in the development of obesity hypertension in C57BL/6 mice. Arterioscler Thromb Vasc Biol 2012, 32:1392-1399.

41. Stanley JA, Aruldhas MM, Yuvaraju PB, Banu SK, Anbalagan J, Neelamohan R, Annapoorna K, Jayaraman G: Is gender difference in postnatal thyroid growth associated with specific expression patterns of androgen and estrogen receptors? Steroids 2010, 75:1058-1066.

42. Castagne R, Zeller T, Rotival M, Szymczak S, Truong V, Schillert A, Tregouet DA, Munzel T, Ziegler A, Cambien F, Blankenberg S, Tiret L: Influence of sex and genetic variability on expression of $\mathrm{X}$-linked genes in human monocytes. Genomics 2011, 98:320-326.

43. Qu M, Tang F, Wang L, Yan H, Han Y, Yan J, Yue W, Zhang D: Associations of ATF4 gene polymorphisms with schizophrenia in male patients. Am J Med Genet B Neuropsychiatr Genet 2008, 147B:732-736.

44. Orozco G, loannidis JP, Morris A, Zeggini E: Sex-specific differences in effect size estimates at established complex trait loci. Int J Epidemiol 2012, 41:1376-1382.

45. Tabernero MD, Espinosa AB, Maillo A, Rebelo O, Vera JF, Sayagues JM, Merino M, Diaz P, Sousa P, Orfao A: Patient gender is associated with distinct patterns of chromosomal abnormalities and sex chromosome linked geneexpression profiles in meningiomas. Oncologist 2007, 12:1225-1236.

46. Reinius B, Johansson MM, Radomska KJ, Morrow EH, Pandey GK, Kanduri C, Sandberg R, Williams RW, Jazin E: Abundance of female-biased and paucity of male-biased somatically expressed genes on the mouse Xchromosome. BMC Genomics 2012, 13:607.

47. Mozhui K, Lu L, Armstrong WE, Williams RW: Sex-specific modulation of gene expression networks in murine hypothalamus. Front Neurosci 2012, 6:63.

48. Taniwaki M, Takano A, Ishikawa N, Yasui W, Inai K, Nishimura H, Tsuchiya E, Kohno N, Nakamura Y, Daigo Y: Activation of KIF4A as a prognostic biomarker and therapeutic target for lung cancer. Clin Cancer Res 2007, 13:6624-6631.

49. Nino-Soto Ml, Nuber UA, Basrur PK, Ropers HH, King WA: Differences in the pattern of $\mathrm{X}$-linked gene expression between fetal bovine muscle and fibroblast cultures derived from the same muscle biopsies. Cytogenet Genome Res 2005, 111:57-64

50. Muller $\mathrm{CR}$, Migl $\mathrm{B}$, Traupe $\mathrm{H}$, Ropers $\mathrm{HH}$ : X-linked steroid sulfatase: evidence for different gene-dosage in males and females. Hum Genet 1980, 54:197-199.

51. Yazarloo F, Shirkoohi R, Mobasheri MB, Emami A, Modarressi MH: Expression analysis of four testis-specific genes AURKC, OIP5, PIWIL2 and TAF7L in acute myeloid leukemia: a gender-dependent expression pattern. Med Oncol 2013, 30:368.

52. Kameswaran V, Bramswig NC, McKenna LB, Penn M, Schug J, Hand NJ, Chen Y, Choi I, Vourekas A, Won KJ, Liu C, Vivek K, Naji A, Friedman JR, Kaestner $\mathrm{KH}$ : Epigenetic Regulation of the DLK1-MEG3 MicroRNA Cluster in Human Type 2 Diabetic Islets. Cell Metab 2014, 19:135-145.

53. TargetScanHuman. [http://www.targetscan.org/]

54. Transcription Factor Search. [http://www.cbrc.jp/research/db/TFSEARCH.html]

55. Lee DK, Cheng R, Nguyen T, Fan T, Kariyawasam AP, Liu Y, Osmond DH, George SR, O'Dowd BF: Characterization of apelin, the ligand for the APJ receptor. J Neurochem 2000, 74:34-41.

56. Guo L, Li Q, Wang W, Yu P, Pan H, Li P, Sun Y, Zhang J: Apelin inhibits insulin secretion in pancreatic beta-cells by activation of PI3-kinasephosphodiesterase 3B. Endocr Res 2009, 34:142-154.

57. Pahl HL: Activators and target genes of Rel/NF-kappaB transcription factors. Oncogene 1999, 18:6853-6866.

58. Eizirik DL, Sandler S, Welsh N, Cetkovic-Cvrlje M, Nieman A, Geller DA, Pipeleers DG, Bendtzen K, Hellerstrom C: Cytokines suppress human islet function irrespective of their effects on nitric oxide generation. J Clin Invest 1994, 93:1968-1974.

59. Bendtzen K, Mandrup-Poulsen T, Nerup J, Nielsen JH, Dinarello CA, Svenson M: Cytotoxicity of human pl 7 interleukin-1 for pancreatic islets of Langerhans. Science 1986, 232:1545-1547.

60. Mahdi T, Hanzelmann S, Salehi A, Muhammed SJ, Reinbothe TM, Tang Y, Axelsson AS, Zhou Y, Jing X, Almgren P, Krus U, Taneera J, Blom AM, Lyssenko V, Esguerra JL, Hansson O, Eliasson L, Derry J, Zhang E, Wollheim CB, Groop L, Renstrom E, Rosengren $\mathrm{AH}$ : Secreted frizzled-related protein 4 reduces insulin secretion and is overexpressed in type 2 diabetes. Cell Metab 2012, 16:625-633.

61. Liu P, Keller JR, Ortiz M, Tessarollo L, Rachel RA, Nakamura T, Jenkins NA, Copeland NG: Bcl11a is essential for normal lymphoid development. Nat Immunol 2003, 4:525-532.

62. Yu Y, Wang J, Khaled W, Burke S, Li P, Chen X, Yang W, Jenkins NA, Copeland NG, Zhang S, Liu P: Bcl11a is essential for lymphoid development and negatively regulates p53. J Exp Med 2012, 209:2467-2483.

63. Gao Y, Wu H, He D, Hu X, Li Y: Downregulation of BCL11A by siRNA induces apoptosis in B lymphoma cell lines. Biomed Rep 2013, 1:47-52.

64. He D, Wu H, Ding L, Li Y: Combination of BCL11A siRNA with vincristine increases the apoptosis of SUDHL6 cells. Eur J Med Res 2014, 19:34.

65. Wu H, Li Y: Gene expression profile analysis of SUDHL6 cells with siRNAmediated BCL11 A downregulation. Cell Biol Int 2014, 38:1205-1214.

66. Cauchi S, Ezzidi I, El Achhab Y, Mtiraoui N, Chaieb L, Salah D, Nejjari C, Labrune Y, Yengo L, Beury D, Vaxillaire M, Mahjoub T, Chikri M, Froguel P: European genetic variants associated with type 2 diabetes in North African Arabs. Diabetes Metab 2012, 38:316-323.

67. Jonsson A, Ladenvall C, Ahluwalia TS, Kravic J, Krus U, Taneera J, Isomaa B, Tuomi T, Renstrom E, Groop L, Lyssenko V: Effects of common genetic variants associated with type 2 diabetes and glycemic traits on alpha- and beta-cell function and insulin action in humans. Diabetes 2013, 62:2978-2983.

68. Langberg KA, Ma L, Sharma NK, Hanis CL, Elbein SC, Hasstedt SJ, Das SK: Single nucleotide polymorphisms in JAZF1 and BCL11A gene are nominally associated with type 2 diabetes in African-American families from the GENNID study. J Hum Genet 2012, 57:57-61.

69. Tang L, Wang L, Ye H, Xu X, Hong Q, Wang H, Xu L, Bu S, Zhang L, Cheng J, Liu P, Ye M, Mai Y, Duan S: BCL11A gene DNA methylation contributes to the risk of type 2 diabetes in males. Exp Ther Med 2014, 8:459-463.

70. Bindom SM, Hans CP, Xia H, Boulares AH, Lazartigues E: Angiotensin Iconverting enzyme type 2 (ACE2) gene therapy improves glycemic control in diabetic mice. Diabetes 2010, 59:2540-2548.

71. Chhabra KH, Xia H, Pedersen KB, Speth RC, Lazartigues E: Pancreatic angiotensin-converting enzyme 2 improves glycemia in angiotensin IIinfused mice. Am J Physiol Endocrinol Metab 2013, 304:E874-E884. 
72. Kode A, Mosialou I, Silva BC, Joshi S, Ferron M, Rached MT, Kousteni S: FoxO1 protein cooperates with ATF4 protein in osteoblasts to control glucose homeostasis. J Biol Chem 2012, 287:8757-8768.

73. Yoshizawa T, Hinoi E, Jung DY, Kajimura D, Ferron M, Seo J, Graff JM, Kim JK, Karsenty G: The transcription factor ATF4 regulates glucose metabolism in mice through its expression in osteoblasts. J Clin Invest 2009, 119:2807-2817.

74. Liew CW, Bochenski J, Kawamori D, Hu J, Leech CA, Wanic K, Malecki M, Warram JH, Qi L, Krolewski AS, Kulkarni RN: The pseudokinase tribbles homolog 3 interacts with ATF4 to negatively regulate insulin exocytosis in human and mouse beta cells. J Clin Invest 2010, 120:2876-2888.

75. Lin HM, Lee JH, Yadav H, Kamaraju AK, Liu E, Zhigang D, Vieira A, Kim SJ, Collins H, Matschinsky F, Harlan DM, Roberts AB, Rane SG: Transforming growth factor-beta/Smad3 signaling regulates insulin gene transcription and pancreatic islet beta-cell function. J Biol Chem 2009, 284:12246-12257.

76. Morgan $C P$, Bale TL: Sex differences in microRNA regulation of gene expression: no smoke, just miRs. Biol Sex Differ 2012, 3:22.

77. Wang H, Maechler P, Antinozzi PA, Hagenfeldt KA, Wollheim CB: Hepatocyte nuclear factor 4alpha regulates the expression of pancreatic beta -cell genes implicated in glucose metabolism and nutrient-induced insulin secretion. J Biol Chem 2000, 275:35953-35959.

78. Chen YA, Choufani S, Ferreira JC, Grafodatskaya D, Butcher DT, Weksberg R Sequence overlap between autosomal and sex-linked probes on the Illumina HumanMethylation27 microarray. Genomics 2011, 97:214-222.

79. Jeppsson JO, Jerntorp P, Sundkvist G, Englund H, Nylund V: Measurement of hemoglobin A1c by a new liquid-chromatographic assay: methodology, clinical utility, and relation to glucose tolerance evaluated. Clin Chem 1986, 32:1867-1872.

80. Olsson AH, Yang BT, Hall E, Taneera J, Salehi A, Nitert MD, Ling C: Decreased expression of genes involved in oxidative phosphorylation in human pancreatic islets from patients with type 2 diabetes. Eur $\rfloor$ Endocrinol 2011, 165:589-595.

81. Rosengren AH, Braun M, Mahdi T, Andersson SA, Travers ME, Shigeto M, Zhang E, Almgren P, Ladenvall C, Axelsson AS, Edlund A, Pedersen MG, Jonsson A, Ramracheya R, Tang Y, Walker JN, Barrett A, Johnson PR, Lyssenko V, McCarthy Ml, Groop L, Salehi A, Gloyn AL, Renstrom E, Rorsman P, Eliasson L: Reduced insulin exocytosis in human pancreatic beta-cells with gene variants linked to type 2 diabetes. Diabetes 2012, 61:1726-1733.

82. Volkmar M, Dedeurwaerder S, Cunha DA, Ndlovu MN, Defrance M, Deplus R, Calonne E, Volkmar U, Igoillo-Esteve M, Naamane N, Del Guerra S, Masini M, Bugliani M, Marchetti P, Cnop M, Eizirik DL, Fuks F: DNA methylation profiling identifies epigenetic dysregulation in pancreatic islets from type 2 diabetic patients. EMBO J 2012, 31:1405-1426.

83. Vikman J, Jimenez-Feltstrom J, Nyman P, Thelin J, Eliasson L: Insulin secretion is highly sensitive to desorption of plasma membrane cholesterol. FASEB J 2009, 23:58-67.

84. Teschendorff AE, Menon U, Gentry-Maharaj A, Ramus SJ, Gayther SA, Apostolidou S, Jones A, Lechner M, Beck S, Jacobs IJ, Widschwendter M: An epigenetic signature in peripheral blood predicts active ovarian cancer. PLOS One 2009, 4:e8274.

85. Du P, Zhang X, Huang CC, Jafari N, Kibbe WA, Hou L, Lin SM: Comparison of Beta-value and M-value methods for quantifying methylation levels by microarray analysis. BMC Bioinformatics 2010, 11:587.

86. Du P, Kibbe WA, Lin SM: lumi: a pipeline for processing Illumina microarray. Bioinformatics 2008, 24:1547-1548.

87. Smyth GK: Linear models and empirical bayes methods for assessing differential expression in microarray experiments. Stat Appl Genet Mol Biol 2004, 3:Article3.

88. Smyth GK: Limma: linear models for microarray data. In Bioinformatics and Computational Biology Solutions using $R$ and Bioconductor. New York: Springer; 2005:397-420.

89. Irizarry RA, Bolstad BM, Collin F, Cope LM, Hobbs B, Speed TP: Summaries of Affymetrix GeneChip probe level data. Nucleic Acids Res 2003, 31:e15.

90. Rainer J, Sanchez-Cabo F, Stocker G, Sturn A, Trajanoski Z: CARMAweb: comprehensive R- and bioconductor-based web service for microarray data analysis. Nucleic Acids Res 2006, 34:W498-W503.

91. Yang BT, Dayeh TA, Volkov PA, Kirkpatrick CL, Malmgren S, Jing X, Renstrom E, Wollheim CB, Nitert MD, Ling C: Increased DNA methylation and decreased expression of PDX-1 in pancreatic islets from patients with type 2 diabetes. Mol Endocrinol 2012, 26:1203-1212.

92. Klug M, Rehli M: Functional analysis of promoter CpG methylation using a CpG-free luciferase reporter vector. Epigenetics 2006, 1:127-130.
93. Hohmeier HE, Mulder H, Chen G, Henkel-Rieger R, Prentki M, Newgard CB: Isolation of INS-1-derived cell lines with robust ATP-sensitive K+ channel-dependent and -independent glucose-stimulated insulin secretion. Diabetes 2000, 49:424-430.

94. R Development Core Team: R: A language and environment for statistical computing. Vienna, Austria: R Foundation for Statistical Computing; 2011.

doi:10.1186/s13059-014-0522-z

Cite this article as: Hall et al:: Sex differences in the genome-wide DNA methylation pattern and impact on gene expression, microRNA levels and insulin secretion in human pancreatic islets. Genome Biology 2014 15:522.

\section{Submit your next manuscript to BioMed Central and take full advantage of:}

- Convenient online submission

- Thorough peer review

- No space constraints or color figure charges

- Immediate publication on acceptance

- Inclusion in PubMed, CAS, Scopus and Google Scholar

- Research which is freely available for redistribution

Submit your manuscript at www.biomedcentral.com/submit
C Biomed Central 